Çukurova Üniversitesi Mühendislik Mimarlık Fakültesi Dergisi, 29(1), 1-26 ss., Haziran 2014

Çukurova University Journal of the Faculty of Engineering and Architecture, 29(1), pp. 1-26, June 2014

\title{
Parajenezlerinde Sülfürlü Mineraller İçeren Maden Yataklarında Oluşabilecek Asit Kaya (Maden) Drenajlarının Çevresel Etkileri
}

\author{
Mesut ANIL ${ }^{1^{*}}$ \\ ${ }^{1}$ Ç.Ü., Mühendislik-Mimarlık Fakültesi, Maden Mühendisliği Bölümü, Adana
}

\begin{abstract}
Özet
Madenler diğer kaynaklardan farklı olarak bir kez çıkarıldıklarında yerlerine yenilerinin konulamayacağı nadir doğal kaynaklardandır. Bu sebeple insanlığın bu kaynakları hem bugünkü nesil ve hem de gelecek nesillerin ihtiyaçlarını karşılayacak şekilde doğa ve kaynak arasında denge kurarak tüketmek ve bunun için de çok iyi bir plan yapması gerekmektedir. Madencilerin bu güne kadarki uygulamalarına bakıldığında en az yatırımla en fazla kar elde etme prensibiyle hareket ettikleri görülmektedir. Günümüzde aranan en önemli faktörlerden biri olan çevreye duyarlılık ilkesi, çıkarılacak madenin kalite standardı ile birlikte ilksel durumundan son kullanma noktasına kadar uygulanan arama, üretme, cevher hazırlama ve izabe işlemlerinde en öne geçmiş durumdadır. Yaşanan bir dizi olumsuzluklar üzerine çevre bilincinin de yaygınlaşmasıyla madencilerin faaliyetleri mercek altına alınarak siyasi iradelerce pek çok yaptırım uygulanmaya konulmuştur. İște bu yaptırımların en yenilerinden olan Asit Kaya veya Asit Maden drenajının oluşup oluşmayacağı başta sülfürlü madenler olmak üzere birçok maden işletme ruhsatı için hazırlanacak ÇED raporlarında ayrı başlık altında istenmeye başlanmıştır. Dünyada son 50 yıl içinde ortaya çıkan bu sorgulama ülkemizde de 20 yıldır sorgulanmaya başlanmış durumdadır. Bu çalışmada Asit Kaya/Maden drenajı hakkında genel bilgiler verildikten sonra verilen ve sülfürlü mineraller içeren bir maden sahasında bu drenajın nasıl gelişebileceği ve daha projelendirme safhasında nasıl bir öngörü hazırlanacağı örneklerle belirtilmiştir.
\end{abstract}

Anahtar Kelimeler: Sülfürlü mineraller, Asit drenajı, Nötürleştirme ve çevresel etki

\section{Environmental Impacts of Mine Ores Containing Sulfurous Minerals in the Paragenesis}

\begin{abstract}
Unlike other resources, mines are rare natural resources which cannot be replaced after extraction. So, It needs to be planned to consume them adequately to meet the needs of both the present and coming generation by establishing a balance between nature and sources. In regard to Miners operation, it is observed that it has been obtained maximum profits from these resources with minimal investment. Nowadays, environmental awareness is one of the most important factors which besides searching principle, mine's quality standards, exploration, production, ore dressing and smelting operations are increasing fast. Experienced a number of negative environmental awareness on the activities, miners
\end{abstract}

\footnotetext{
* Yazışmaların yapılacağı yazar: Mesut ANIL, Ç.Ü. Mühendislik Mimarlık Fakültesi, Maden Mühendisliği Bölümü, Adana.manil@cu.edu.tr
} 
work under the strict supervision and so many sanctions has been adopted by political powers. One the newest of these sanctions according to which whether acid rock or acid mine drainage will occur or not, particularly in sulfur mines, is preparing ÇED report for this and other mineral operations under different title for getting mining licenses. Scrutinizing about mineral operations which emerged in the world in the last 50 years was started in our country in last 20 years. After introducing acid rock / mine drainage generally, this study attempted to investigate how these drainage would be developed in the sulfide minerals- contained mine site and how this project planning phase is foreseen.

Key words: Sulfures paragenesis, Acid drainage, Neutralisation, Environmental impacts

\section{GİRIŞ}

Madenler diğer zenginlik kaynaklarından farklı olarak bir kez üretildiklerinde yenilerinin yerlerine koyulamayacağı nadir doğal kaynaklardandır. $\mathrm{Bu}$ sebeple insanlığın bu kaynakları gerek bugünkü nesil ve gerekse de gelecek nesillerin ihtiyaçlarını karşılayacak şekilde doğa ve kaynak arasında denge kurarak tüketilmesi ve bunun için de çok iyi bir plan yapması gerekmektedir. Önceki yıllarda bugünün gelişmiş ülkelerinde bile bu plan ve programların çok iyi yönetildiği söylenemez. Genellikle madencilerin en az yatırımla en fazla kar getirecek şekilde madenin de en yüksek tenörlü olanını doğayı da fazla düşünmeden madencilik faaliyetlerini gerçekleștirdikleri bilinmektedir. Bu günün en modern ülkelerinde bile 1950 öncesine ait çok kötü madenciliğin yapıldığına dair örnekler bulunmaktadır.

Günümüzde istenen en önemli faktörlerden biri olan çevreye duyarlılık ilkesi çıkarılacak madenin kalite standardı ile birlikte ilk doğal halinden kullanılabilirlik aşamasına kadar kullanılan arama, üretme, cevher hazırlama ve izabe işlemlerinde en öne geçmiş unsurdur. Çevreye zarar vermeme ilkesi bütün gelişmiş toplumlarda artık yadsınamaz hale gelmiştir. Hatta bütün yasal işlemleri yerine getirmiş ve çevre kirliliği için uluslararası kriterlere göre tedbirlerini almış olduğu halde gerek Türkiye'de ve gerekse dünyanın başka ülkelerinde kamuoyu baskısı sebebiyle gerçekleştirilemeyen madencilik projelerinin sayısı oldukça kabarıktır. Çevre konuları içinde su ve toprak kirlenmesi en az hava kirlenmesi kadar önemli olup, ağır metaller ve toksik (zehirli) elementlerce kirlenmesi son 35 yılda büyük önem kazanmıştır. İlk başlarda yalnızca gelişmiş ve sanayide çok ileri gitmiş ülkelerde ortaya çıkan Asit Kaya Drenaj1 veya Asit Maden Drenaj1 gibi kavramlar son 20 yılda ülkemizde de benimsenmiş ve çevre kriterlerinde özellikle sülfürlü cevher içeren madenlerin işletilmesi sırasında, ișletmeden sonraki evresinde, cevher hazırlama işlemlerinin sona erdirilmesinden sonraki evrelerde asit üreterek su ve toprağı kirletip kirletmeyeceği sorgulanır olmuştur. $\mathrm{Bu}$ tip kirlenmeler atık depoları ve atmosfere açık duran galeri, kuyu ve ocak şevlerinden oluşacak atmosferik suların sızıntıyla yer altı suyunu veya yeryüzünde akan su kaynaklarını ve toprağı kirletmesi mümkün olabilmektedir. Ayrıca atık havuzlarının duvarlarının kaya/dolgu barajlarının çeşitli nedenlerle (heyelan, deprem ve aşırı yağış gibi doğal riskler) çökmesi durumunda büyük çaplı ağır metal kirlenmelerinin oluşması mümkündür. $\mathrm{Bu}$ sebeple daha işin başında atıkların cinsi, miktarı ve bunların uzun vadedeki davranışlarının önceden kestirilmesi ve risk öncesi ve riskin oluşmasını müteakip yapılması gereken tedbirlerin daha işletmeye başlamadan bilinmesi gerekmektedir [14].

Sanayileşen dünya, nüfus artışını körüklemiş bu yüzden de önceleri kendi kendini onarabilen doğa onarma kapasitesi aşıldığı için tahribat gözle görülebilecek düzeye çıkmıştır. Bilim adamları tabiattaki yolunda gitmeyen bir şeyler olduğunu bundan 200 yıl kadar önce ilk kez keşfetmiş ve yeni bir araştırma alanı seçerek dengeleri bozan ve doğanının kendini onarmaya yetmediği durumları tespit ederek onarıma yardım edebilecek çözüm önerilerini ardarda üretmeye başlamıştır. Fakat bundan en fazla 50 yıl öncesine kadar tabiatın karş1 karşıya kaldığı anormal değişiklerin biyosferin ve 
biyosfer içindeki bilhassa insanoğlunun geleceğine ilişkin muhtemel tehlikeler bilim camiası içinde bile sınırlı sayıdaki araştırıcılar dışında pek umursanmamıştır [4].

Günümüzde sönük geçmişine rağmen çevre sorunları ihmal edilemeyecek seviyede önemli bir gerçektir. Acilen dünyada sürüp giden ve doğal dengeyi bozan bu yüzden de başta insanlar olmak üzere tüm canlı alemi tehdit eden kötü uygulamalardan vazgeçilerek yeni yöntemler ve gelişmiş dünyanın bularak uyguladığı ve sonuç aldığ 1 tedbirlerin vakit geçirilmeden gelişmekte olan veya az gelişmiş ülkelerde de hemen uygulanması önem taşımaktadır. Ancak maalesef daha teşhis aşamasında bile sıkıntılar mevcut olup sanayileşmesini bir asır önce gerçekleştiren batı dünyası uzun yıllar boyu artan üretim-tüketim boyutları, yeni pazar arayışları ve aşırı büyüme gösteren ekonomik yapıları sebebiyle çevreyi fazla düşünmemişlerdir. Buna karşılık sanayileşmesini yeni yeni tamamlayan gelişmekte olan ülkelerin bir zamanlar kendilerinin kullanmakta sakınca görmedikleri üretim yöntemlerini kullanmalarına çevre kirliliği yapıyor diyerek müsaade etmeme yolunu tercih etmektedir. Bu da işin başında çevre kirliliği açısından teşhis aşamasında ayrılık doğurmaktadır. 1970'lerde çevre mi ekonomik faaliyet mi? Tartışması gündeme oturmuş ve o yıllarda çözüm için mantıklı bir düşüncenin ortaya çıkmasına engel olmuştur.

Geçmiş nasıl değerlendirilirse değerlendirilsin mevcut çevre sorunlarını doğuran sebepler görmezlikten gelinemeyeceğine göre bir taraftan üretim-tüketim ilişkisi sürdürülürken çevrenin daha da bozularak yaşanamaz hale gelmemesi için çözüm çabalarının sabırla sürdürülmesi önemli görüldüğünden gerek Birleşmiş Milletler Çevre Örgütü, gerek ulusal devletlerin kendi kuruluşları ve gerekse engellenemeyecek derecede büyüyen çevreci sivil toplum örgütleri koruma tedbirlerini yakından denetlemektedirler. Diğer yatırımlarda olduğu gibi sanayileşmenin olmazsa olmaz sektörü konumundaki madencilik alanında 20. Yüzyıla kadar çevre üzerindeki muhtemel etkileri hesaba katılmadan ekonomik, siyasal ve askeri hedeflere paralel maden üretim politikaları yürütülmüştür. Diğer sanayi kollarında olduğu gibi maden işletmeleri ömürlerini doldurup sahalar terk edilirken önceki faaliyetler sırasında oluşan kirlilik, doğanın tahribatı ve sonraki yıllarda oluşması muhtemel tehditlere yönelik tedbirler alınmadan son noktanın konulması mümkün olabilmiştir. $\mathrm{Bu}$ zaman süresince olumsuzluklar yaşanmadığı sürece idari ve adli yaptırımlar da hayata geçirilmemiştir. İşletilmiş maden sahalarının olduğu gibi bırakılmasından bir süre sonra atmosferik yağışlar asidik drenajların oluşmasına sebep olmuş ve yavaş yavaş hem yer altı su kaynakları ve hem de yüzeydeki toprağın ağır metaller (bazıları toksik özellikte olabilir) yönünden kirlenmeye başlamıştır.

1950’lere kadar pek çoğu küçük boyutta ve yeryüzüne yakın konumda olan açık işletmeler daha sonra devasa kazı makinalarının keşfi ve yüksek tenörlü madenlerin azalmasıyla daha düşük tenörlerde ama daha derinlerde yataklanmış madenlerin işletilmeye başlanmasıyla çok büyük boyutlu çukurların oluşmasını doğurmuştur. Bunun üzerine çevre bilincinin de yaygınlaşmasıyla madencilerin faaliyetleri mercek altına alınarak siyasi iradelerce pek çok yaptırım uygulanmaya konulmuştur. İşte bu yaptırımların en yenilerinden olan Asit Kaya veya Asit Maden Drenajının oluşup oluşmayacağı başta sülfürlü madenler olmak üzere birçok maden işletme ruhsatı için hazırlanacak ÇED raporlarında ayrı başlık altında istenmeye başlanmıştır. Dünyada son 40 yıl içinde ortaya çıkan bu sorgulama ülkemizde de 15 yıldır sorgulanmaya başlanmış durumdadır.

\section{ASIT KAYA (MADEN) DRENAJ KAVRAMI}

Başta pirit olmak üzere sülfürlü metalik mineral içeren kömür, sülfür formundaki baz metaller, uranyum ve değerli metal içeren madenlerde görülen asit kaya/maden drenajı sülfürlü minerallerin nemli ortamda bazen de mikrobiyolojik organizmaların katkısıyla oksitlenmesi sırasında drenaj sularının asidik özellik kazanmalarına ve geçtikleri formasyonlar içerisindeki bazı ağır ve toksik elementleri çözerek drenaj suyuna karıştırmalarına asit kaya/maden drenajı denilmektedir. Bu olayda pek çok karmaşık 
ve süksesif kimyasal reaksiyonlar cereyan eder. Asit üreterek sülfürlü minerallerin oksitlenmesini oluşturan reaksiyonlar maden yatakları ve jeokimya kitaplarında 50 yılı aşkın süredir bilinmektedir. $\mathrm{Bu}$ reaksiyonlar basitleştirmiş şekliyle;

$\mathrm{FeS}_{2}+15 / 4 \mathrm{O}_{2}+7 / 2 \mathrm{H}_{2} \mathrm{O} \rightarrow 4 \mathrm{H}^{+}+2 \mathrm{SO}_{4}{ }^{--}+\mathrm{Fe}(\mathrm{OH})_{3}$

Sülfat oluşumu ile pirit gibi öteki sülfürlü mineraller de tetiklenir ve ortamdaki asidite artar. Asidite üretiminde nem, hava ve sülfürlü mineraller birincil etmenler olarak adlandırılmıştır. Buna karşılık ortaya çıkan asidi nötürleştiren ve reaksiyon ürünleriyle tepkimeye giren kalsit ve dolomit gibi mineraller içeren karbonatlar ile daha az etkili bazı silikat mineralleri ikincil etmen olarak tanımlanmıştır. Oluşan asidi nötürleştiren veya reaksiyon ürünleriyle tepkiyenler ikincil, asidin taşınmasında ve tüketilmesinde etken olanlar üçüncül faktörler olarak kabul edilirler. Bunlar oksitlenme sırasında açı̆̆a çıkan asit ile reaksiyona tutuşarak ortamın pH'ını yükselterek çözünmeyi azaltıp nötürleştirmektedir. Bu olay da en basit şekliyle;

$\mathrm{CaCO}_{3}+2 \mathrm{H}^{+} \longrightarrow \mathrm{H}_{2} \mathrm{CO}_{3}+\mathrm{Ca}^{2+}$

reaksiyonu ile ifade edilebilmektedir.

Buna göre, ortamın mineralojik yapısına bağlı olarak, hem oksidasyon, hem de nötürleştirme reaksiyonları gerçekleşebilir. Çoğu kez beşeri faaliyetlerinin dişında tamamen doğal olarak da gelişebilen AMD; düşük pH (yüksek asidite), yüksek iyon konsantrasyonu (zengin metal içeriği), askıda ve çözünmüş katı özellikleriyle çevre üzerinde olumsuz etkiler yaratabilir [5]. Ancak bütün sülfürlü mineralleri içeren maden yataklarının işletilmesinde yankayaç ve gang minerallerinin özelliklerini belirlemeden Asit Kaya/Maden drenajına sebep olacağının ileri sürmek bilimsel bir yaklaşım değildir. Asit Kaya/Maden drenajında ikincil faktör olarak değerlendirilen gerek madenin bulunduğu ana veya yankayacın fiziksel yapıs1, dokusu, tektonik özellikleri ve bölgede hüküm süren iklim durumu oluşacak drenajı büyük ölçüde etkilemektedir. Öte yandan cevher üretildikten sonra zenginleştirme işlemlerine başvuruluyorsa seçilen yöntem, tane boyutu ve kullanılan prosesteki kimyasallar bu asit drenajında elbette etkilidir. Madenin bulunduğu yerin topografik özellikleri de önemli bir etkendir. Asit maden drenajının ilk adımı sülfürlü demir mineralleri (pirit, pirotin, markazit gibi)'nin oksitlenmesi olup, sonra çözünmesiyle ortama yayılır ve pH'nın yükselmesiyle ikincil minerallerin çökelmesiyle de son bulur. Demir şapka (gossan da denir) adı verilen bu durum yüzeye yakın konumda bulunan metalik maden cevherleşmelerinde geliştiğinden gerek hava fotoğrafları ve gerekse günümüzdeki uydu görüntülerinde jeologlar tarafindan maden arama yöntemi olarak kullanılagelmiştir. Oksidasyon zonunun başlangıcı olan bu demir şapkalar atmosferik suların yüzeydeki etkinliği ile asidik drenajı başlatır. Son 50 yılda çevresel bir kaygı olarak değerlendirilen asit drenajların belki de milyonlarca yıldır doğada var olduğu ama doğal dengeyle asiditeyi nötürleştirebilecek reaksiyonlarla korunduğu, dengelenemeyen yerlerde de kirlenmenin süregeldiği bilinmektedir. Her ne kadar adına asit kaya/maden drenajı denilmiş ise de hiç madencilik faaliyeti ile ilgisi olmayan otoyol, havaalanı ve baraj yapımı sırasındaki derin kazıların da asit drenajlarına sebep oldukları bilinmektedir.

Asit maden drenajını yalnızca başta demir olmak üzere sülfür fazındaki metalik madenleriyle gerek üretim ve gerekse cevher hazırlama safhalarıyla sınırlandırmak gerçekçi bir tavır olacaktır. Cevher üretimi yapılırken kazı arınında veya stok sahasında ya da atık yığını ve barajlarının kapladığ1 alanlarda atmosferik sular ve havanın bol oksijeni (rüzgar dahil) ile çözünerek pH'ın düşmesiyle artan asidite asit kaya drenajını oluşturmaktadır. Bazı mikroorganizmaların da bu olayda rol alması mümkündür. Bu sebeple başta kimyasal reaksiyonlarla başlayan bu olay fizikokimyasal, jeokimyasal ve biyokimyasal karaktere bürünmektedir [4]. Parajenezdeki asit üreten bu sülfürlere karşılık gerek gang mineralleri ve gerekse yan kayaç içindeki kalsit-dolomit minerallerinden oluşan karbonatlar ve bazı silikatlar da ortama $\mathrm{OH}$ - iyonu vererek pH'ın yükselmesine yani bazikleşmesine sebep olurlar. Karbonat platformalarındaki cevherleşmelerinde gerek kalsit-dolomit ve gerekse mermer ile kalşist, 
mikaşist gibi kayaçlar görüldüğünden bu kayaçların ortamı nötürleşmede önemli rol oynayacakları açıktır. Günümüze kadar Türkiye'deki uygulamalarda Asit Kaya/Maden drenajlarıyla ilgili sorunlar ve çözümler daha çok işletme ve zenginleştirme sonrasındaki atık barajları ve işletme çukurlarında gelişmesi muhtemel olayların önlenmesine ağırlık verilmiştir. Henüz işletme başlangıcında olan ve asit drenajına sebep olabilecek sülfürlü mineraller içeren cevherlerin işletme öncesinde ne ölçüde asit drenajı oluşturdukları hususunda bazı tahminler yapılmış ise de doğanın kendi kendini tamir etme gücünün oldukça başarılı olduğu, yani asidi üretenlere onu nötürleştiren başta karbonat mineralleri ve bazı silikatların karşı koyduğu varsayımı kabul görmüştür. Fakat son 50 yılda açık işletme yöntemlerindeki gelişmeler, çok büyük rezervli ancak düşük tenörlü cevher yataklarının çok güçlü kazı makinalarıyla işletilmeleri ve zenginleştirilmeleri sırasında geriye kalan dev maden artığı yığınların içindeki özellikle pirit gibi sülfürlü minerallerin varlığı oluşacak drenajın tek başına doğanın kendi imkanlarıyla bu sorunu yenmede başarılı olamayacağı, bu yüzden de çevreyi ve bilhassa su kaynakların korunmasında ilave tedbirlerin alınmasının şart olduğu Birleşmiş Milletler Çevre Komisyonunca belirtince diğer ulus devletlerde de siyasi otoriteler yaptırım uygulamaya başlamışlardır.

\subsection{Asit Kaya (Maden) Drenajı Nasıl Oluşmaktadır}

$\mathrm{Bu}$ konuda ortaya atılan görüşlerin çoğu yabancı ülkelere ait jeolog, jeokimyacı, fizikokimyac1, toprakçı ve ekolojist araştırmacılara aittir. Son 20 y1l içinde ülkemizden de bu konuda araştırma yapanların sayısında belirgin bir artış gözlenmektedir. Birçok jeoloğun (yerli ve yabanc1) bu olayı asit kaya veya asit maden drenajı başlığı ile yorumladığı bilinmektedir. $\mathrm{Bu}$ sebeple bu çalışmada da eş anlamlı olarak kullanılması benimsenmiştir. Asit Kaya/Maden drenajında olayı başlatan ilk reaksiyonun piritin oksitleşmesi olup, reaksiyon denklemi aşağıdaki gibidir. Pirit mineralin su ve hava ile reaksiyonu sonucunda sülfürik asit ve demir hidroksitin oluşumuna asit maden drenajı denir.
$2 \mathrm{FeS}_{2}+7 \mathrm{O}_{2}+2 \mathrm{H}_{2} \mathrm{O} \longrightarrow 2 \mathrm{FeSO}_{4}+2 \mathrm{H}_{2} \mathrm{SO}_{4}$

Pirit yaygın olarak sülfürlü cevherlerde, kömür içerisinde ve kömür cevherini üzerleyen kayalar içerisinde bulunmaktadır. Açık işletme sırasında, pirit içeren kömür veya cevher seviyelerinin hava ve su ile teması AMD oluşumunu tetikler. Sülfürik asidin oluşmasıyla açığa çıkan demir sülfat üç değerli hale geçerek hemen oksitlenir.

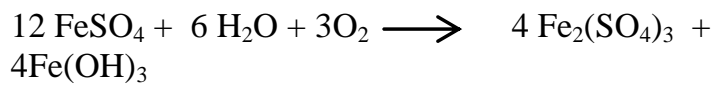

Birçok maden yatakları, jeokimya ve çevre jeolojisi gibi ders kitaplarında açıklandığı gibi üç değerli demir sülfat asit veya nötr ortamda duraysız aynı zamanda da oksitleyicidir. $\mathrm{Bu}$ yüzden ortamdaki başta pirit olmak üzere tüm birincil sülfür minerallerini çözmeye çalışır. Demir sülfürlerin çözünmeleri sülfürik asit ve feri-ferro sülfatların oluşumunu öteki sülfürlü mineralleri tetiklemeleri ortamın çözünürlüğünü hızlandırır. Demir sülfürlerin diğer bir rolü de elektrolit etkileri sonucu $\mathrm{Zn}-\mathrm{Pb}-\mathrm{Cu}$ sülfürlerin oksidasyon oranlarını artırmasıdır. Eğer primer cevherde demir sülfür mineralleri bulunmaz ise oksitleşme olayları oldukça yavaş ilerler.

AMD oluşumunun ürünleri olan asidite ve demir, su kaynaklarının $\mathrm{pH}$ 'nı düşürerek ve akarsu tabanını demir oksit çökelleriyle kaplayarak su kaynaklarını kullanılamayacak duruma sokmasıdır. Zaman zaman arazilerde gözlenen akarsu yatağı ve maden çevresinde gelişen portakal renkli alanlar asit maden drenajının demir oksit çökelimi sonucudur (Şekil 1-2).

Asit Maden Drenajını aşağıdaki reaksiyonlarla daha yakından inceleyelim:

$$
\begin{aligned}
& 4 \mathrm{FeS}_{2(\mathrm{k})}+14 \mathrm{O}_{2(\mathrm{~g})}+4 \mathrm{H}_{2} \mathrm{O}_{(\mathrm{s})} \longrightarrow 4 \mathrm{Fe}_{2+(\text { çöz })}+
\end{aligned}
$$

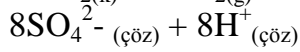

$$
\begin{aligned}
& 4 \mathrm{Fe}^{2+}(\text { çöz })+\mathrm{O}_{2}(\mathrm{~g})+4 \mathrm{H}+(\text { çöz }) \longrightarrow 4 \mathrm{Fe}_{3}+(\text { çöz }) \\
& +2 \mathrm{H}_{2} \mathrm{O}_{(\mathrm{s})} \\
& 4 \mathrm{Fe}^{3+}(c ̧ \mathrm{öz})+12 \mathrm{H}_{2} \mathrm{O}(\mathrm{s}) \longrightarrow 4 \mathrm{Fe}(\mathrm{OH})_{3}(\mathrm{k})+ \\
& 12 \mathrm{H}+(\text { çöz })
\end{aligned}
$$




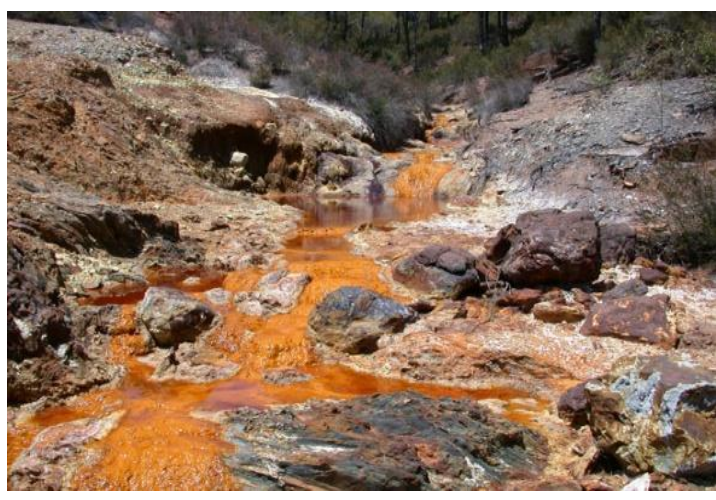

Şekil 1. Asit maden drenaj1 sonunda akarsu yatağında oluşan çökelmelere örnek, acide rock drainage figures:http://en. Wikipedia.org/wiki/Archaea

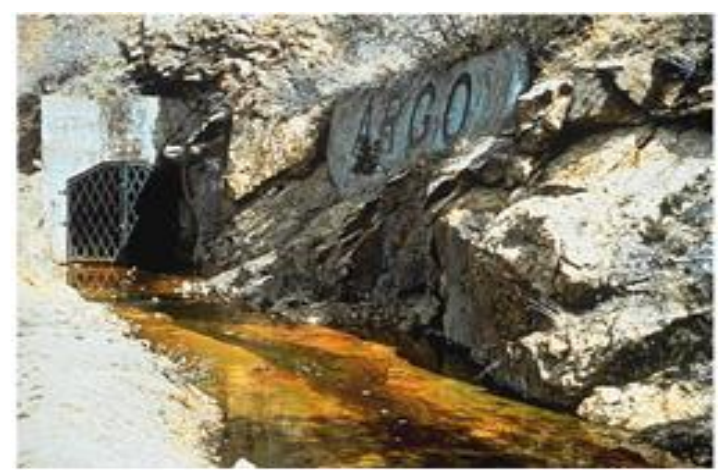

Şekil 2. 200 yll çalıştıktan sonra rezerv tükenmesi sonucu kapatılan en eski altın madeni olan Argo'dan geriye kalan asit maden drenaj1 [7].

Asit maden drenajında bakterilerin de önemli rolü belirtilmekte ve özellikle maden artıkları ve atık havuzlarında artık malzeme içinde pirit bulunması halinde eğer büyük oranda Thiobacillus ferrooxidans bakterisi de varsa asit maden drenajını oluşturmaktadır. Düşük $\mathrm{pH}$ ortamlarda yaşayabilen bu bakteri piritin oksidayosnunu, $\mathrm{Fe}^{+3}$ ve $\mathrm{H}^{+}$oluşumuna neden olmaktadır. 4 ve 5 nolu reaksiyonda Thiobacillus ferrooxidans bakterisinin katalizör görevi gördüğü belirtilmektedir. Bunun sonucundan meydana gelen 6 . Reaksiyon biyolojik kökenli değildir [4].
$\mathrm{FeS}_{2}+3.5 \mathrm{O}_{2}+\mathrm{H}_{2} \mathrm{O} \longrightarrow \mathrm{Fe}^{2+}+2$

$\mathrm{SO}_{4}^{2-}+2 \mathrm{H}^{+}$

$2 \mathrm{Fe}^{2+}+0.5 \mathrm{O}_{2}+2 \mathrm{H}^{+} \longrightarrow 2 \mathrm{Fe}^{3+}+\mathrm{H}_{2} \mathrm{O}$

$\mathrm{FeS}_{2}+14 \mathrm{Fe}^{3+}+8 \mathrm{H}_{2} \mathrm{O} \longrightarrow 15 \mathrm{Fe}^{2+}+2 \mathrm{SO}_{4}{ }^{2-}+$

$16 \mathrm{H}^{+}$

Asit maden drenaj1 anaerobik ortamda bile gelişebilmektedir.

anaerobik ortam

$\mathrm{S}+6 \mathrm{Fe}_{3}{ }^{+}+4 \mathrm{H}_{2} \mathrm{O} \longrightarrow \mathrm{H}_{2} \mathrm{SO}_{4}+6 \mathrm{Fe}_{2}^{+}+6 \mathrm{H}^{+}$

Sülfürlü mineralleri içeren cevher üretimi sırasında kazılan yan kayaç artıklarından oluşan yığınlar, üretim ve yapılan hazırlıklar sürekli yeni yüzeylerin açılmasını doğurur. Bu yüzden de açık ve kapalı ocaklar, cevher stok sahaları, başta pirit olmak üzere sülfürlü cevher konsantre stokları, zenginleştirme prosesleri sonundaki atık ve artık havuzları asit maden drenajının oluşmasına sebep olabilir. Atmosferik etkilerle (su ve hava) oluşacak sızıntılar ve yüzey drenajları asit maden drenajını oluşturur ve oradan akarsulara, göllere ve düşey sızıntılarla yeraltı suyuna taşınıp karışabilir (Şekil $3)$.

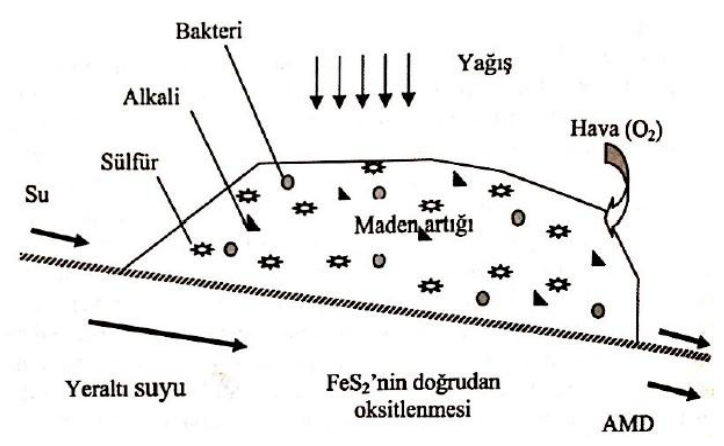

Şekil 3. Asit maden drenaj1 oluşum mekanizmasının şematik gösterimi [8].

Asit Maden Drenajının çeşitli yollarla su kaynaklarına karışması ve drenaj suyu içindeki ağır ve bazen de toksik (zehirleyici) metal konsantrasyonları suların kalitesini olumsuz etkileyebilir. Etkilenen bu suların kendi debileri, içerdikleri metal konsantrasyonları bölgedeki akarsuların bolluğu, klimatolojik değerler seyreltilmeyi sağlayacaklarından dolayı kirlenme derecesinde oldukça etkilidirler. Her maden sahasının kendine has asit drenajı üretme 
potansiyeli ve oluşan bu asiditeyi nötürleştirecek ya da azaltacak karşı koyma potansiyeli bulunmaktadır. Bu sebeple genel prensipleri aynı sayılan fakat uygulamada farklılıklar gösteren sülfürlü mineral içeren maden sahalarının mineralojik ve kimyasal özellikleri ayrıntılarıyla incelenerek yankayaç ve gang minerallerinin bileşimleri de dikkate alınarak pasif ve aktif yöntemler hem işletme öncesi kestirimler yapılarak, hem de işletme sırasında önlemler alarak asit drenajlarına karşı koyulmaktadır. Maden ömrünü tamamladıktan sonra da gerekli tedbirler alınarak artık yığınları ve derin çukurlar ve basamaklar oluşan işletme sahasının asit üretmemesi için önlemler alınarak kontrol kuyularından takip işlemleri tavizsiz yürütülmelidir.

\subsection{Asit Kaya (Maden) Drenajını Tetikleyen Etmenler}

Her sülfürlü cevher içeren maden asit drenaj1 üretmez. Pirit, Pirotin ve Markazit içeren her maden de mutlaka asit drenajı oluşur demek de doğru değildir. Eğer öyle oluşmuş olsaydı günümüze kadar geçen süre içinde milyonlarca kez asit drenajları oluşmuş, bu mineraller oksitlenmiş ve ilksel konumlarını koruyan hiçbir pirit, pirotin ve markazite rastlamamamız gerekirdi. Oysa doğada böyle bir durum yoktur. Başta demir sülfür içeren minerallerin oksitlenebilmesi için olmazsa olmaz şartlardan biri oksijen bolluğudur. İkincisi de nemdir. $\mathrm{Bu}$ ya doğrudan su ile temas veya nemli atmosferle temasla gerçekleşir. Bu iki olayın her ikisinin de eş zamanlı etkilemesi olmadan oksitlenme tam manasıyla gerçekleşemez. EPA, 1994 standartlarına göre sülfürlü minerallerin oksitlenmesinde daha önce de belirtildiği gibi sülfürlü mineraller+su+hava birincil etmenler, ortaya çıkan asidi nötürleştiren ya da yeni oluşan ikincil minerallerle reaksiyona tutuşan kalsit ve dolomit ile bazı silikat mineralleri ikincil etmenler, sülfürlerin oksitlenmesiyle oluşan asidin taşınmasını yol güzergahında tüketilmesinde rol oynayan üçüncül etmenler ayırt edilmiştir. En az 100 yıldır bilinen oksidasyon ve semantasyon zonlarında gelişen reaksiyonlardan özellikle oksidasyon zonundaki dönüşümler sonunda asit kaya/maden drenajının oluştuğu anlaşılmaktadır.
Oksidasyon zonunda görülen kimyasal olaylar da daha önce verilen sülfürlü minerallerin değişikliğe uğramasına sebep olan reaksiyonlarla büyük benzerlikler göstermektedir. Oksidasyon zonlarında en yaygın sülfür minerallerinden olan pirit bu zonda değişikliğe uğramaktadır. Oksidasyon ve semantasyon zonları arasındaki sınırın Garrels 1953 tarafından [6] Cu-Pb-Zn mineralleri için deneysel duyarlılık alanları için Eh-pH diyagramında önerdiği gibi $\mathrm{pH}=2, \mathrm{Eh}=$ 0,2 noktası ile $\mathrm{pH}=10, \mathrm{Eh}=-0,2$ noktalarını birleştiren düz bir çizgiyle ayrılmaktadır (Şekil 4).

$$
2 \mathrm{FeS}_{2}+7 \mathrm{O}_{2}+2 \mathrm{H}_{2} \mathrm{O} \longrightarrow 2 \mathrm{FeSO}_{4}+2 \mathrm{H}_{2} \mathrm{SO}_{4}
$$

Ortamda bir defa sülfürik asit oluşunca açığa çıkan 2 değerli demir sülfat 3 değerli demir sülfat haline geçerek oksitlenir. Bu dönüşümden hem üç değerli demir sülfat, hem üç değerli demir hidroksit ve hem de yeni su molekülleri oluşur.

$$
\begin{aligned}
& \begin{array}{l}
12 \mathrm{FeSO}_{4}+6 \mathrm{H}_{2} \mathrm{O}+3 \mathrm{O}_{2} \longrightarrow \\
4 \mathrm{Fe}(\mathrm{OH})_{3}
\end{array} \mathrm{Fe}_{2}\left(\mathrm{SO}_{4}\right)_{3}+ \\
& 12 \mathrm{FeSO}_{4}+6 \mathrm{H}_{2} \mathrm{O}+3 \mathrm{O}_{2} \longrightarrow 4 \mathrm{Fe}_{2}\left(\mathrm{SO}_{4}\right)_{3}+4 \mathrm{Fe} \\
& (\mathrm{OH})_{3} \\
& 4 \mathrm{FeSO}_{4}+2 \mathrm{H}_{2} \mathrm{SO}_{4}+\mathrm{O}_{2} \longrightarrow 2 \mathrm{Fe}_{2}\left(\mathrm{SO}_{4}\right)_{3}+2 \mathrm{H}_{2} \mathrm{O}
\end{aligned}
$$

Ancak üç değerli demir sülfat nötür veya az asit olan ortamda duraysız olduğundan reaksiyonlar durmaz. Ortamdaki su ile birleşerek üç değerli demir hidroksit ve yeni sülfürik asit üretir.

$$
\mathrm{Fe}_{2}\left(\mathrm{SO}_{4}\right)_{3}+6 \mathrm{H}_{2} \mathrm{O} \longrightarrow 2 \mathrm{Fe}(\mathrm{OH})+3 \mathrm{H}_{2} \mathrm{SO}_{4}
$$

Ayrıca üç değerli demir sülfat önemli bir oksitleyici olup primer sülfür minerallerini de oksitleyerek ortama yeni minerallerin çıkmasına yardımcı olur.

$$
\mathrm{Fe}_{2}(\mathrm{SO} 4)_{3}+\mathrm{FeS}_{2} \longrightarrow 3 \mathrm{FeSO}_{4}+2 \mathrm{~S}
$$

Açığa çıkan bu kükürt ya $\mathrm{SO}_{2}$ veya $\mathrm{H}_{2} \mathrm{SO}_{4}$ haline geçer. Benzer şekilde pirotin ve markazit de çözünür. Bu olaylar sonunda sülfürik asit ve feriferro sülfatların oluşması parajenezde varsa öteki sülfür minerallerin çözünmelerini hızlandırır.

$\mathrm{Fe}_{2}\left(\mathrm{SO}_{4}\right)+\mathrm{Cu}_{2} \mathrm{~S} \longrightarrow \mathrm{CuSO}_{4}+2 \mathrm{FeSO}_{4}+\mathrm{CuS}$ 

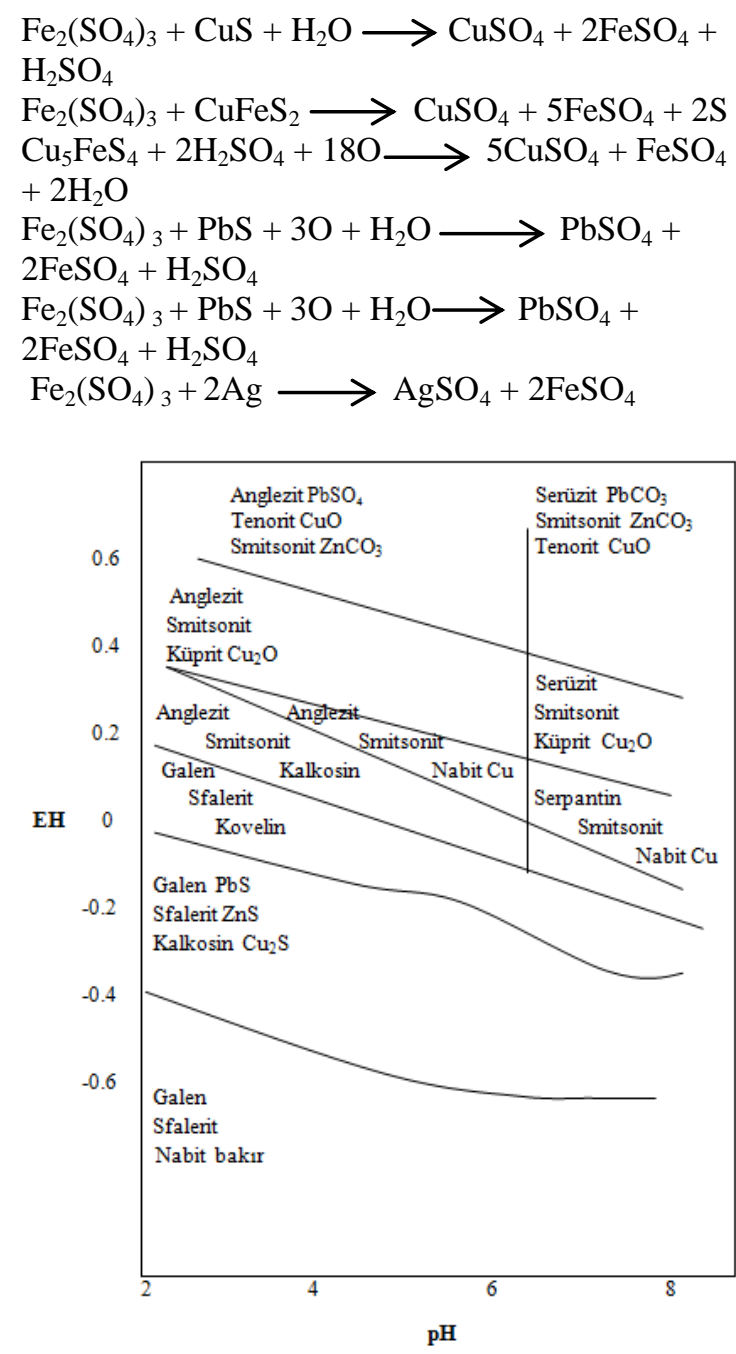

Şekil 4. Bazı bakır, kurşun ve çinko mineralleri için duraylılık alanları [6].

Cevher mineralleri içinde demir sülfürlerin de bulunmasi elektrolit etkisi yaparak $\mathrm{Zn}-\mathrm{Pb}-\mathrm{Cu}$ sülfürlerin oksidasyon oranını artırması dolayısıyla da asit drenajını yükseltmesidir. Şayet primer cevherde demir sülfürler yoksa oksidasyon çok yavaş ilerler, dolayısı ile de ortama verilen asit sınırlı kalır.

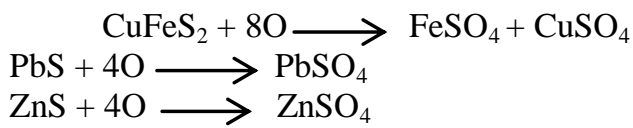

Yukarıdaki reaksiyon denklemleriyle verilen kimyasal olaylar sonucunda ilk etapta metal sülfatların arttığı anlaşılmaktadır. Derinlere doğru çözeltilerdeki oksijen miktarının ve $\mathrm{H}_{2} \mathrm{SO}_{4}$ 'ün azalarak tükendiği görülmüştür. $\mathrm{Bu}$ yüzden asit kaya/maden drenajında esas sorun bu drenajın oluştuğu oksidasyon zonu olup, yer altı su tablasının (semantasyon zonu) altında asit drenajı oluşamaz.

Oksidasyon ortamının nötür veya hafif asitkuvvetli asit olmasına göre de farklı elementler çökelir. Örneğin nötür veya hafif asit ortamlarda üç değerli demir hidroksit $\left(\mathrm{Fe}(\mathrm{OH})_{3}\right)$, çeşitli elektrolitlerin etkisiyle jel halinde çöker. Bu jel form daha sonra suyunu kaybederek limonite dönüșür. Bundan sonra da $\mathrm{HFeO}_{2} / \mathrm{FeO}(\mathrm{OH})$ halinde götit oluşur. Karıncadağ cevher zonlarından alınan örneklerin gerek mineralojik tayinlerinde ve gerekse XRD mineral faz diyagramında bu minerallerin ikisi de sıkça görülmüştür.

Bir diğer husus da bitişik veya birlikte bulunmaların minerallerin farklı davranışlarından dolayı oksitlenmeleri tek başına bulunduklarından değişik davranmalarıdır. Değişiklik iki sebepten olabilir. Bir sülfürlü mineralin oksidasyonu ile ortaya çıkan yeni bileşikler diğerini etkileyebilir. Birbirinden farklı elektrik yükü olan iki element sülfürle yan yana bulunursa elektropotansiyeli az olanı elektrik yükünü üstüne çeker. Bu durum ise elektrik aktivitesi yüksek olan minerali tek başına bulunması durumundan daha kolay oksitlenmesini sağlar. Buna karşıllı daha aktif bir sülfür, tek başına olduğundan daha geç ve daha yavaş oksitlenir. Örneğin markazit sfalerite göre daha elektrik aktivitesine sahip bir mineraldir. Ancak sfaleritle kontak halindeyken yalnız başına olduğu zamandan 4 ile 6 defa daha yavaş oksitlenmektedir.

Oksidasyon zonunda cevher çökelmeleri genellikle oksit, hidroksit, karbonat, sülfat ve doğal (nabit) metal olarak gerçekleşmektedir. Daha seyrek olarak da vanadat, arseniyat, uranat, molibdat, holojenür ve silikatlar şeklindedir. Sülfatlı çözeltiler şayet yantaş karbonatsa onlarla reaksiyona girerek $\mathrm{Pb}, \mathrm{Zn}, \mathrm{Cu}, \mathrm{Fe}$ karbonatlarının 
çökelmesine olanak verirler. Bazı sülfatlar ise eriyemediklerinden çökelirler $\left(\mathrm{PbSO}_{4}\right.$ /Anglezit gibi). Eğer yankayaç silikatlı bir bileşime sahipse o zaman da krizokol, hemimorfit gibi silikatli mineraller oluşabilir. Eğer yankayaç yavaş tepkime gösteren bir özellikteyse o zaman sülfatlar daha derinlere kadar inebilir asidite oranı düşer ortam hafifçe indirgen (Eh negatif) bu zaman da ikincil sülfür mineralleri görülür ki, Karıncadağ kompleks cevherleşmelerinde yan kayaç içinde yeterince karbonat olduğundan ikincil sülfür mineralleri pek yaygın değildir.

Asit kaya/maden drenajını etkileyen faktörler arasında karstlaşma da oldukça önemlidir. Bölgedeki $\mathrm{Zn}-\mathrm{Cu}-\mathrm{Pb}-\mathrm{Fe}$ cevherleşmelerinde asit drenajından söz edilmeden birincil sülfür minerallerinin oksitlenmesini müteakip oksitli ve karbonatlı cevher mineralleri oluşurken son safhada karstlaşma evriminin de rol oynadığ görüşü son yıllarda yapılan araştırmalarda dile getirilmiştir. Gerek Akdağ, Karıncadağ ve Bolkardağ cevherleşmelerinde yan kayacın karbonat ağırlıklı olması karstik boşlukları açılmasına sebep olmuştur. Gerçekten de Karıncadağ'da cevher içeren galerilerden girilebilinenlerde ilk önce sülfürlü minerallerle başladığı daha sonra karstik mağaralara kadar devam ettiği ve bu kısımlarda oksitli ve karbonatlı cevherlerin ağırlıklı olduğu vurgulanmıştır [9,10;11]. Yine karbonatlı kayaçlar içinde yerleşen Engizek (K.Maraş), Zamantı (Kayseri) $\mathrm{Pb}-\mathrm{Zn}-\mathrm{Cu}-$ $\mathrm{Ba}$ cevherleşmelerinde de karstik evrimden bahsedilmiştir [12,13].

Karstlaşmanın asit kaya/maden drenajıyla ilgisini inceleyecek olursak pirit, pirotin ve markasit gibi demir sülfür minerallerinin oksitlenmesi sonunda ortaya çıkan iki değerli metal sülfatların öteki sülfür minerallerini dönüşüm (tersinir) reaksiyonlarla etkiledikleri ve ortamın asidite oranına göre yeni ikincil minerallerin oluşmasını sağladıkları 1950'li yıllardan beri bilinmektedir. Bu konuda oldukça fazla sayıda ayrıntılı çalışmalar gerçekleştirilmiştir. Ancak 1990'lı yıllardan sonra Türkiye'de gündeme getirilen asit drenajlarıyla ilgileri fazlaca araştırılmamıştır. Şimdi oksidasyon zonunda başlayan dönüşümlerden başlayarak daha aşağı zonlara kadar gidebilen ve burada ikincil sülfür minerallerini oluşturarak duraylı hale geçebilen minerallerin hangi formlarının asit drenajına sebep olabileceklerini nitelik ve nicelik yönüyle yakından inceleyelim.

$$
\begin{aligned}
& \mathrm{M}^{1++} \mathrm{SO}_{4}^{--}(\text {Çözelti })+\mathrm{MS}(\text { Kristal I) } \\
& \mathrm{M}^{++} \mathrm{SO}_{4}^{-}(\text {Çözelti })+\mathrm{M}^{1} \mathrm{~S}(\text { Kristal II })
\end{aligned}
$$

Bu reaksiyon denkleminde 1 nolu kristal magmatik (hipojen) kökenlidir. Oksidasyon sonucunda II nolu kristal tarafindan ornatılmıştır. Burada çözelti halindeki iki değerlikli metal sülfat ki, genellikle başlangıçta demirdir olayı hızlandırmakta ve ortamın asiditesini artırmaktadır. Öte yandan meteorik (atmosferik) oksidasyon sonucu birincil sülfürlerin bozuşmasıyla oluşan sülfatlar eğer tüm jeokimyasal bariyerleri geçerek yeraltı su tablasının altına kadar ulaşırlarsa nisbeten indirgen ve durgun sulu ortamda birincil sülfür mineralleriyle karşılaşırlarsa metal katyonlarını çökeltirler. Önceleri fazla ayrıntıya girilmeden jeokimyacı-metallojenist araştırıcıların ilgi alanındaki bu konulara 1950'li yılların başından itibaren termodinamikçi araştırıcıların yeni buluşlarıyla ivme kazandırılmış ve serbest entalpi kavramları ile açıklanmıştır.

Semantasyon zonuna kadar inen ve karstlaşmayla son bulan bu olaylar oldukça özel koşullar olup, $\mathrm{Eh}, \mathrm{Ph}$, Sicaklık, basınç ve biraz da $\mathrm{CO}_{2} \mathrm{k}$ sımi basıncı ve çözelti içindeki S'ün varlığı ile şartlandığı belirtilmiştir [6]. Bu koşulları dikate alırsak sistemi termodinamik kuramlarına göre aşağıdaki gibi yazmak mümkündür.

$$
\begin{aligned}
& \mathrm{CO}_{2}=\mathrm{MHCO}_{3}{ }^{-}+\mathrm{MH}_{2} \mathrm{CO}_{3}+\mathrm{MCO}_{3}^{--}=10^{-1.5} \\
& \mathrm{~mol} / \mathrm{lt} \text { (eğer ortam yalnızca } \mathrm{CO}_{2} \mathrm{k}_{1 \mathrm{sm}} \text { basınc1 } \\
& \text { etkisindeyse) } \\
& \mathrm{S}=\mathrm{MSO}_{4}^{--}+\mathrm{MS}+\mathrm{MHS}^{-}+\mathrm{MH}_{2} \mathrm{~S}=10^{-1} \mathrm{~mol} / \mathrm{lt} \\
& \text { (eğer ortamda } \mathrm{S} \text { varsa) }
\end{aligned}
$$

Verilen bir katyonun (örneğin $\mathrm{Pb}$ ) tuzlu çözeltilerinin Eh ve $\mathrm{pH}^{\prime}$ in herhangi bir değeri için, i yonlar arası reaksiyonları ve katyonun tuzlarının çözünürlüklerini saptamak mümkündür.

$$
\mathrm{pH}=-\log \left(\mathrm{H}^{+}\right) \text {olduğuna göre; }
$$


Büyük termodinamikçi Lamiter (1938) tarafından belirlenen Pb'nin su tablasının durgun seviyesi ile mostra arasındaki doğal solüsyonlar içinde oluşan çözünürlük denge sabitleri aşağıda verilmiştir.

$$
\begin{array}{ll}
\mathrm{aPb}^{+2} \times \mathrm{aS}^{-2} & =\mathrm{K}_{\mathrm{PbS}}=10^{-29} \\
\mathrm{aPb}^{+2} \times \mathrm{aCO}_{3}^{-2} & =\mathrm{K}_{\mathrm{PbCO} 3}=10^{-12.8} \\
\mathrm{aPb}^{+2} \times \mathrm{aSO}_{4}^{-2} & =\mathrm{K}_{\mathrm{PbSCO} 4}=10^{-7.75} \\
\frac{\mathrm{aH}^{+} \times \mathrm{aCO}_{3}^{-2}}{\mathrm{aHCO}_{3}^{-}} & =\mathrm{K}_{\mathrm{HCO} 3}{ }^{-}=10^{-10.5} \\
\frac{\mathrm{aH}^{+} \times \mathrm{aHCO}_{3}^{-}}{\mathrm{aH}_{2} \mathrm{CO}_{3}} & =\mathrm{K}_{\mathrm{H} 2 \mathrm{CO} 3}=10^{6.5} \\
\frac{\mathrm{aH}_{+} \mathrm{aS}^{-2}}{\mathrm{aHS}^{-}} & =\mathrm{K}_{\mathrm{HS}}^{-}=10^{-16} \\
\frac{\mathrm{aH}+. \mathrm{aHS}^{-}}{\mathrm{aH}} & =\mathrm{K}_{\mathrm{H} 2 \mathrm{~S}}=10^{-7}
\end{array}
$$

Daha sonraki bu alandaki çalışmalar Şekil 5'de görülen Garrels[6]. diyagramındaki koordinatların sülfatların sülfürlere nazaran duyarlılık alanlarını belirtmeye ideal olmadığını göstermiștir. Gerçekten de oksido-redüksiyon reaksiyonları, sülfatlar ile sülfürler arasında oluşan normal bir kimyasal reaksiyon değildir. Ortam koşullarına göre ve özellikle sıcaklığa bağlı olarak bu reaksiyonlar tersine de olabilir. Ancak hemen her zaman bakteriler katalizör etkisi yaptıklarından, sülfatların birbirini etkilediği normal reaksiyonlar gibi gelișirler. Bu yüzden Garrels [6]'in diyagramı gerçeğe en yakın bir durum olup, büyük bir çoğunlukla ilgi görmüştür.

Öte yandan pH ve Eh'ın değișim alanları (Şekil 6a ve $6 \mathrm{~b}$ 'deki taralı kısım) $A B$ hattı karstik sistemdeki süzülme zonuna ait suların $\mathrm{pH}$ ve Eh değerlerini olgun veya ihtiyarlık devresindeki karstik bir sistem için göstermektedir.

Reaksiyonları ise;

$$
\begin{gathered}
\mathrm{S}^{-2}+4 \mathrm{H}_{2} \mathrm{O} \longrightarrow \mathrm{SO}_{4}^{-2}+8 \mathrm{H}+8 \mathrm{e} \\
\mathrm{E}=-0,4 \mathrm{Vile} \\
\mathrm{E}_{\mathrm{h}}=\mathrm{E}_{0}+\frac{R T}{M F} \mathrm{Ln} \frac{\left(s O_{4}^{-2}\right)\left(H^{+}\right)}{S^{-2}} \text { Nernst Denklemi }
\end{gathered}
$$

Konsantrasyonları ve aktiflikleri alt üst edeceği sanılan bu kurallar zayıf iyonik çaplı solüsyonlarda önemsizdir [14].
Örneğin, $\mathrm{pH}=1 \mathrm{Eh}=+0,4 \mathrm{v}$ olursa ortam çok asit özellikte ve iyi oksitleyici olacaktır.

$$
\left(\mathrm{Pb}^{+2}\right) \mathrm{SO}_{4}=10^{-6.75} \quad\left(\mathrm{~Pb}^{+2}\right)_{\mathrm{CO} 3}=10^{3.7}
$$

Karbonat ve sülfüre göre daha küçük iyonik potansiyele sahip $\mathrm{Pb}$ sülfat anyonu ile birlikte teşkil edeceği mineral mevcut şartlarda daha az eriyebilme kabiliyetine sahip olduğundan daha duyarlı olacaktır.

Şekil 6‘da görüldüğü gibi nokta nokta hareket ederek Pb'nin çeşitli tuzlarının duyarlılık alanları tespit edilebilir.

Karstik olaylardaki pH - Eh koşullarındaki $\mathrm{Pb}$ ve Zn'nin farklı duyarlılık alanlarını Şekil 6'da karşılaştırarak görmek mümkündür. Karstlaşmanın 1slatma zonundaki sülfürlü metallerin duyarlılık kazanmaları için şu sonuçlar gereklidir.

1.Sülfürleşmeler için yeterince kükürt bulunmalıdır: Çünkü karstik suların jeokimyasal temayülleri gittikçe sülfatlaşma yönündedir.

2.Sülfatların indirgenerek sülfürler şekline dönüşebilmesi için reaksiyonların hızlı gelişmesi şarttır.

Zira sadece kristalli bir ortamda düşünülen oksidoredüksiyon denklemlerinin önceden olmaması gerekiyor. Fakat bilindiği gibi bunlar iki tersinir denklemde ayrışırlar. Birinci hızlı gelişen sülfatlaşma ikincisi ise ağır oluşan sülfürleşme denklemleridir. Ancak bunlar daha öncede değindiği gibi bakterilerin etkisiyle normal kimyasal denklemler gibi gelişirler. Yüzeysel sülfürleşmeler bakterilerin etkisiyle olur. $\mathrm{Bu}$ olay biter bitmez (örneğin $\mathrm{T}>70^{\circ} \mathrm{C}$ olduğu zaman), sulu çözelti ortamında sülfatların indirgenmesi düşük bir hızla tersinir bir reaksiyonla başlar.

Asit kaya/maden drenajında etkili birincil faktörlerden olup demir sülfürlerin oksitlenmesinde rol oynayan oksijen (aerobik ortam) ve su kadar mikrobiyolojik aktivite de reaksiyon hızlarına etki etmektedir. Oksitlenme başlamadan önce genellikle ortamda bulunan suların pH'ı nötür veya ona yakın değerdedir. Sürecin başlayabilmesi atmosferik oksijenin 
varlığına bağlıdır. Oksijen yalnızca reaksiyonu başlatmakla kalmamakta ve bilhassa ortamın pH's1 3,5 altına indiğinde bakterilerin etkisiyle oksitlenmenin sürebilmesi için de gereklidir.

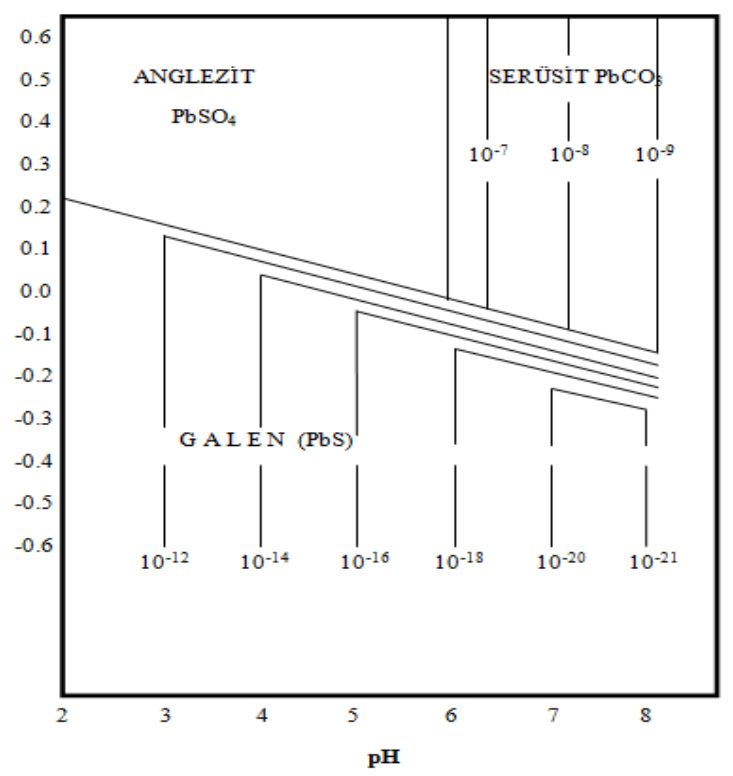

Şekil 5. $\mathrm{Pb}$ ve Zn'nin çözünürlüklerinin fonksiyonu olarak teorik duraylılık alanları diyagramı [6].

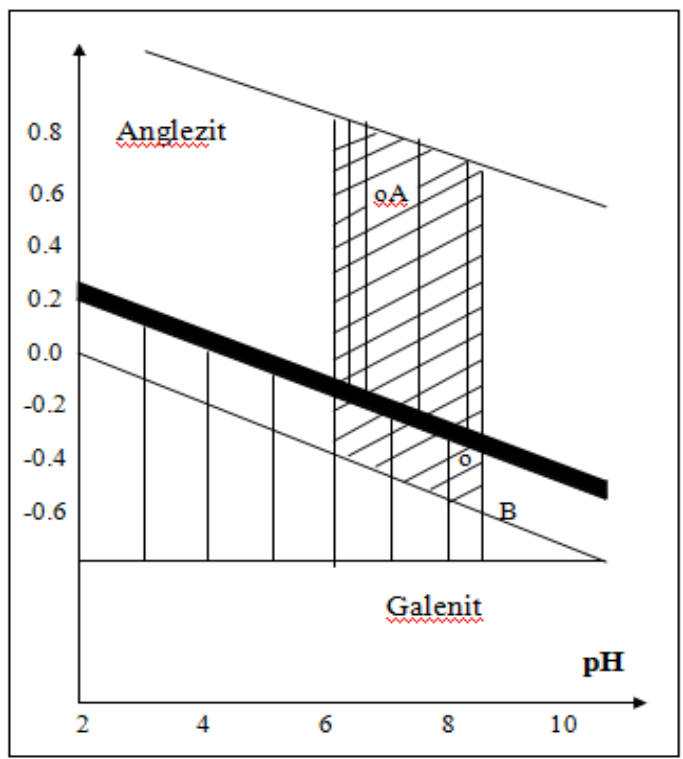

(a)
$\mathrm{Bu}$ olayda rol oynayan sülfürlü minerallerin parçalanması-çözünmesinde ilk parametre $\mathrm{pH}$ olup, bu nötür durumundan her iki yönde uzaklaşıldığında çözünme hızları artmaktadır. Bu sebeple değişik pH aralıklarında iyonların etkinliği jeokimyasal olarak belirlenebilmektedir. Şekil 7'de değişik pH değerlerine göre drenajın karakterinin değiştiği ve asit kaya, nötür maden ve tuzlu drenaj gibi kısımların oluştuğu görülmektedir. Ph'ın 2-4,5 derecelerinde yalnızca asit kaya drenajı gelişirken, 4,5-7,2 dereceleri arasında nötür maden drenaj1, 7,2-10 dereceleri arasinda tuzlu metal çözeltilerinin çökeleceği görülmektedir.

Drenajda yer alan minerallerin aktifliği yalnızca ortamın asiditesinin artmasıyla açıklanamaz. Başta kalsit ve dolomit gibi karbonatl mineraller ile bazı silikatlar oksitlenme sonunda çıkan asit ile reaksiyona girerek ortamı tekrar nötürleştirirler. Ayrıca suda bulunan proton ve çeşitli metal iyonlarının da parajenezdeki minerallerle reaksiyona girerek ortaya çıkacak yeni ürünlere sebep olduklarından drenajın kimyasında da değişiklikler görülür. Eğer yantaş veya gang içinde karbonatlı mineraller sülfürlü minerallerin tamamını tüketecek kadar bolsa o zaman asidik drenaj hiç gelişmeyebilir. $\mathrm{Bu}$ durumda dahi metalik minerallerin çözünerek suya çeşitli metal

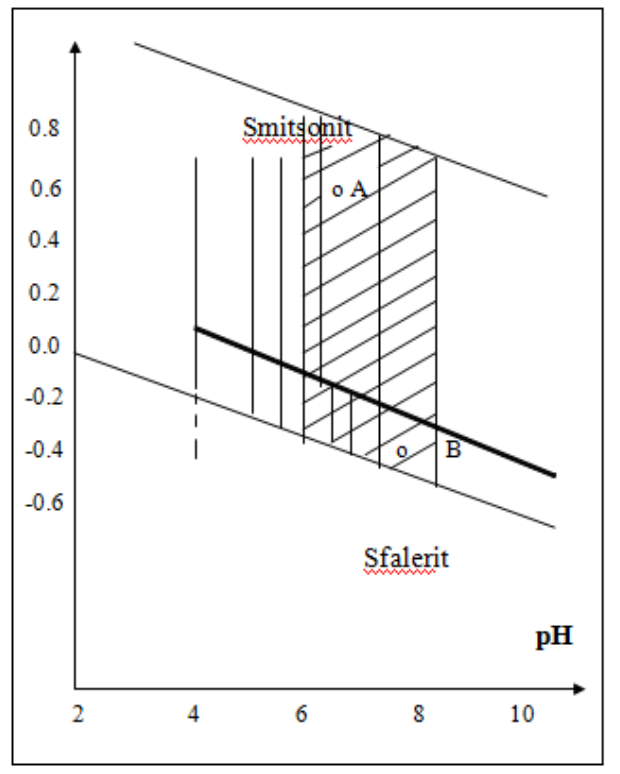

(b)

Şekil 6. Karstik sistemde Pb'nin davranışı (a)Karstik sistemde Zn'un davranışı (b) [6]. 
Typical relation to drainage $\mathrm{pH}$ :

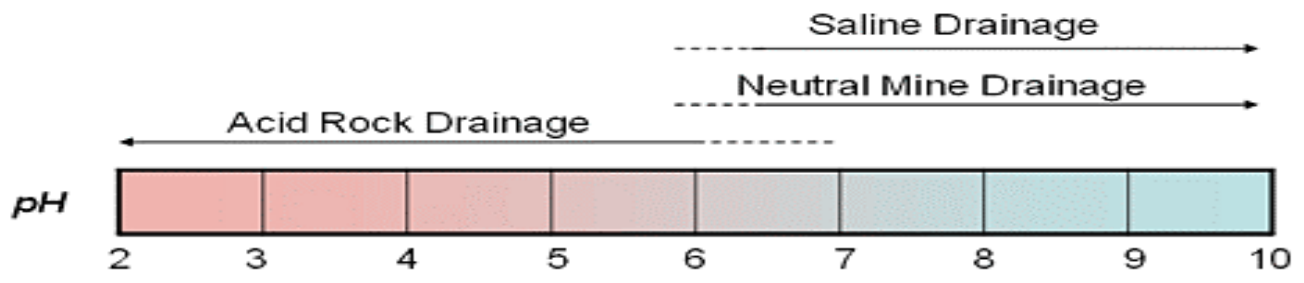

Typical drainage characteristics:

\begin{tabular}{|l|l|l|}
\hline Acid Rock Drainage: & Neutral Mine Drainage: & Saline Drainage: \\
- acidic pH & - near neutral to alkaline pH & - neutral to alkaline pH \\
- moderate to elevared & - low to moderate metals. & - low metals. Mary have \\
metals & May have elevated zinc. & moderate iron. \\
- elevated sulphate & cadmium, manganese. & - moderate sulphate. \\
- treat for acid neutralization & antimony, arsenic or & magnesium and calcium \\
and metal and sulphate & selenium. & - treat for sulphate and \\
removal & - low to moderate sulphate & sometimes metal removal \\
& - treat for metal and & \\
& sometimes sulphate removal & \\
\hline
\end{tabular}

Şekil 7. Farklı pH değerlerine göre drenaj çeşitleri [15].

iyonlarını (Pb-Zn-Cu,Mn,Al, Co, Ni, As gibi) vermesine engel olunamaz eğer silikat mineralleri arasında killeşme başlamışsa iyon değişismleri sürer ve jips çökelmesi gerçekleşebilir.

Asit drenajında fiziksel faktörlerde önemli olmaktadır. Madenin bulunduğu ilk konumdaki durumu, yankayaç bileşimi, faylanmalar ve öteki süreksizlikler, tabaka arası boşluklar, geçirgenlik gibi özellikler önemli rol oynarlar. Öte yandan en önemli drenaj sorunu olan cevher çıkarılıp bir dizi cevher hazırlama işleminden geçirilip geriye bırakılan, pasa, artık ve atık yığınları içindeki malzeme boyutu ve öteki fiziksel özellikleri de drenajın gelişme hızı üzerinde etkilidir. Cevher içeren yankayacın ne kadar çok incelmesi yüzey alanlarını o derece arttırması sebebiyle iri boyuttayken duraylı olan yani asit üretmeyen sülfürlü minerallerin küçük boyutlara indirildiğinde oksitlenmelerinin artacağı çok eskiden beri bilinen bir gerçektir. Buna karşılık malzeme boyutu arttığında reaksiyon hızı düşer ama bu sefer taneler arası açıldığı için oksijen ve suyun daha kolay temas etmesi gerçekleştiğinden oksitlenme çabuk gelişir.

Asit drenajında madenin bulunduğu bölgenin iklimi, topografik yapısı da önemlidir. Yağışlar yüzey sularını artırırlar ve yığınlar üzerinde daha fazla sızıntı gerçekleştirdiklerinden taşınma kolaylaşır. Ancak yığının suya doygunluğu artacağından oksidasyon hızı yavaşlar. Benzer şekilde rüzgarın da etkisi değişik sonuçlar doğurur. Özellikle iri taneler arasındaki atmosfer basıncını yükseltir hava dolaşımının artması oksitlenmeyi hızlandırır.

Yüzey şekilleri de asit drenajında etkilidir. Eğer plato şeklinde bir arazide sülfürlü mineraller içeren bir maden varsa yüzey suları uzun süre sızıntılara sebep olup ortamdan çabucak uzaklaşamaz ve oluşan asit drenajını da seyreltmede yetersizdir. Buna karşılık sarp topografik topografya seyreltmeye daha elverişlidir. Karıncadağ kompleks cevherleşmeleri böyle bir topografyadadir.

\subsection{Asit Kaya Drenajının Oluşmasını Sağlayan Mekanizmalar}

$\mathrm{Bu}$ oluşum kimyasal, jeokimyasal, biyokimyasal ve fiziko kimyasal özellikler taşıyan olaylar sonucu gerçekleşir. Bu kadar kompleks olaylardan hangisinin hangi safhada ne kadar etkin olduğunu belirlemek de oldukça güçtür. 


\subsubsection{Kimyasal Mekanizmalar}

Önceki bölümlerde belirtildiği gibi asit drenajı oluşturan sülfürlü minerallerden pirit, pirotin ve markazit içinde tepkimeye kimyasal aktivitesi itibariyle bu üç mineral arasında en düşük olan piritin başrol oynaması sülfürlü cevherleşmelerde diğer ikisine göre çok yaygın olarak parajenezde yer almasındandır. Bu olaylarda pirit çok uzun yıllardan beri baş etkileyici olarak ele alınmış ve piritin oksitlenme mekanizması, kinetiği ve bakteri oluşumunun reaksiyonlardaki rolü sayısız bilimsel araştırmaya konu edilmiştir.

Sülfürlü mineral içeren madenlerin gerek ilk işletme sırasında yeni açılan yüzeylerde ve gerekse depolanan (cevher yığını, pasa yığını veya artıkatık yığını) içinde az veya çok oranda bulunan pirit oksitleyici bir ortama kavuşunca ilk etapta asit üretimini başlatır. $\mathrm{Bu}$ reaksiyonların çeşitli şekillerde tepkime denklemlerini önceki bölümlerde belirtmiş olmakla beraber burada daha yakından inceleyecek olursak;

$\mathrm{FeS}_{2}$ (kristal-katı) $+\mathrm{H}_{2} \mathrm{O} \longrightarrow \mathrm{Fe}^{2+}$ (katı iyon) $+2 \mathrm{SO}_{4}^{2-}$ (çözelti) $+2 \mathrm{H}^{+}+1 \mathrm{~S} 1$

Ekzotermik bir reaksiyon olan olayda bir molekül piritin oksitlenmesi sonunda ikişer molekül proton $\left(\mathrm{H}^{+}\right)$ve sülfat iyonu çözeltiye karışırken ortama da 1s1 verilmektedir. Ortamda yeterince oksijen olduğunda indirgenerek hidrojen iyonlarını nötürleştirir ve su oluşurken iki değerlikli $\mathrm{Fe}$ oksitlenerek 3 değerlikli demir oluşur.

$\mathrm{Fe}^{2+}(\mathrm{kat} 1)+\mathrm{O}_{2}(\mathrm{gaz})+2 \mathrm{H}^{+} \longrightarrow \mathrm{Fe}^{3+}$ (katı) $+2 \mathrm{H}_{2} \mathrm{O}$ (çözelti)

Ortamın asitliği arttığında (pH 3,6-5) $\mathrm{Fe}^{3+}$ (katı) iyonunun çözünürlüğü artacağından oksijenden daha güçlü bir oksitleyici olmaktadır. Bu yüzden de piritin daha hızlı oksitlenmesi başlar. Sülfat iyonları ile birlikte ortamda bulunan üç değerlikli demir iyonları, sudaki hidroksit iyonlan ile tepkime ürünü olan demir hidroksiti vererek hidrolize olur.

$\mathrm{Fe}^{3+}+3 \mathrm{H}_{2} \mathrm{O} \longrightarrow \mathrm{Fe}(\mathrm{OH})_{3}(\mathrm{k}) \downarrow+3 \mathrm{H}^{+}$
Ortamın pH'ına bağlı olarak demir hidroksit sarıdan kırmızıya kadar değișen renklerde çökelerek suyun rengini de değiştirir. Ortamın asiditesi artığında çözünürlüğü hızla artan $\mathrm{Fe}^{3+}$ çözeltide kalır. Daha sonra ise üç değerlikli demir iyonları birincil demir sülfürlerle tekrar reaksiyona tutuşarak ortama yeniden $\mathrm{Fe}^{2+}$ iyonları salarak bir önceki olay tekrarlanır.

$$
\begin{aligned}
& \mathrm{FeS}_{2}(\mathrm{k})+14 \mathrm{Fe}^{3+}+8 \mathrm{H}_{2} \mathrm{O} \longrightarrow 15 \mathrm{Fe}^{2+}+2 \mathrm{SO}_{4}{ }^{2-}(\mathrm{s}) \\
& +16 \mathrm{H}^{+}
\end{aligned}
$$

Buradaki kimyasal reaksiyonlar bu kadarla sınırlı olmayıp diğer birincil metal sülfürleri, bakteriler ve ikincil mineraller de kimyasal sürece katılırlar. $\mathrm{Bu}$ reaksiyonlar daha önce görülen oksidasyon zonundaki tepkimelerin hemen hemen aynısıdır. Metallerin bozunma ve yeni ürün çökeltme kapasiteleri çözünürlük değerleri ve parajenezden çözeltiye geçerken konsantrasyon oranlarıyla belirlenir.

\subsubsection{Jeokimyasal Mekanizmalar}

Asit maden drenajı karışık bir dönüşümdür. Ancak özde minerallerin çözünmesi, ardından katı hale geçerek çökelmesi ve yeniden çözünmesiyle şekillenen süreçler dizisidir. Bu olayın oluşup oluşmaması asit üreten veya onu nötürleştiren minerallerin suyla etkileşimleri neticesinde belirlenir. Maden sahasıyla temas eden suların mevcut minerallerden çözünebilenlerini çözmesi, çözünen iyonların yeniden katı faza dönüşerek çökelmesiyle (presipitasyon) ikincil minerallerin meydana gelmesi ve nihayet bunların tekrar çözünerek suya geçmesi, drenaj sularının fiziksel ve kimyasal özelliklerini tayin eder. Olayların bu basit analizi, söz konusu maden yatağının jeokimyasal niteliğinin suların asit karakter kazanıp kazanmaması açısından önemini göstermektedir.

Sülfür minerallerinin çözünerek çökelmeye uğraması sırasında oluşacak konsantrasyon zamanın fonksiyonu olarak su ile minerallerin temasta kalma süreleri olayda önemli rol oynamakta ve bu süre yeterince uzun olursa reaksiyonlar dengeye ulaşabilmektedir. Drenaj suyu başka bir mineralle reaksiyona tutuştuğunda 
dengenin değişip yeni bir kinetik dönemin başlayacağı açıktır.

Drenajın ikinci etabı ikincil mineralleri oluşumu ile başlamakta ve bu sürede sülfatlar, karbonatlar, hidroksitler gibi ikincil minerallerin çözünürlükleri doygunluk sınırına ulaşınca çökelmeler başlamaktadır. Sülfür fazında reaksiyon kinetikleri oldukça yüksek olmasına rağmen bu bölümde yavaşlarlar ve sonunda duraylı bir hal alırlar. Birincil sülfür minerallerin çözünmesi ve ikincil sülfat, karbonat ve hidroksil minerallerin çökelmesi ilk aşamayı teşkil etmektedir. İkinci aşamada, ikincil mineraller ve çözünürlüğü az (tepkimeye girme kabiliyeti daha düşük) birincil sülfür minerallerin çözünmesi gerçekleşir [4]. Son aşama ise, çözünürlüğü çok düşük birincil ve ikincil minerallerin yavaşça çözünmesini içerir. Böylece birinci aşamayla erken dönem, ikinci aşamayla orta dönem ve son aşamayla da geç dönem drenaj kimyası şekillenmiş olur.

Asit Kaya/Maden drenajında reaksiyonlar asiditeye kaynaklık eden minerallerin çözünmesinden ibaret değildir. Cevher parajenezlerinde çözündüğü zaman ortamın pH'ını yükselterek ortamın alkaliliğini artıran ve ara denge oluşturan mineraller de bulunabilir. Pirit, pirotin gibi demir minerallerinin oksitlenmesiyle asiditesi yükselen drenaj suları, bünyesinde karbonatları barındıran kayaçlarla temas ettiğinde, onları çözündürür. $\mathrm{Bu}$ esnada asit tüketimiyle ortam $\mathrm{pH}^{\prime} 1$ yükselme eğilimine girer. Ortamın nötürleşmesinde en etkin mineraller kalsit, dolomit ve ankerittir. Çözünme hızları kalsit $>$ dolomit $>$ siderit $>$ manyezit olarak verilmektedir. Ancak, demir ve mangan karbonatların, oksitleyici ortam koşullarında, net asit nötürleşmesi sağlamayacağına, çünkü suya geçen demir ve manganezin oksitlenmeye maruz kalacağına, bunu da hidroliz ve presipitasyonun takip edeceğine, bir dizi tepkime sonunda asit üretimine katkı yapacaklarına işaret edilmiştir [16]

Anortit ve forsterit gibi silikatların çözünmesiyle de asit nötürleşir. Fakat, silikatlar karbonatlara kıyasla daha yavaş çözeltiye geçerler. Dolayısıyla, etkinlikleri, asit üretim hızının yavaşlığına bağlıdır. İlk çözünme sonrasında gelişen ve tabii ki, başka doğal olaylara bağlı olan bazı fiziksel ve kimyasal süreçler, oluşan çözeltinin niteliğini, bu aşamadan itibaren doğrudan etkiler. Çözünmeyi takiben çözelti atmosfer etkisine maruz kaldığında oksitlenme, seyrelme, karışma, buharlaşma ve nötürleşme gibi faktörler mineral çökelmesini doğurur ve ikincil mineral oluşumları meydana gelebilir. İkincil minerallerin gelişmesi artık yığınları, maden atıkları ve yüzey akıntısı kıyıları gibi değişik alanlarda görülebilir [4]. Çözündüklerinde ise, metal salabilirler, ortamı nötürleştirebilir veya drenajın asiditesini arttırabilirler. Ayrica, $\mathrm{AI}^{3+}, \mathrm{Fe}^{3+}, \mathrm{Fe}^{2+}$ ve $\mathrm{SO}_{4}^{2-}$ iyonlarının aktivitelerini kontrol ederken, gelişen hidroliz tepkimeleri de $\mathrm{pH}^{\prime} 1$ tayin eder [17].

Asit Kaya/Maden Drenajın nötürleşmesinde önemli roloynayan karbonatlı ikincil mineralle $\mathrm{Cu}$, $\mathrm{Pb}$ ve $\mathrm{Zn}$ cevherlerinin oksitlenmesiyle meydana oluşmaktadır (Çizelge 1).

Genel anlamda, kolay ya da uygun koşullar altında çözünebilen mineraller drenaj niteliğinde belirleyicidirler. Doğal olarak, ikincil mineral oluşumlarında maden yatağının jeokimyasal yapısı mineralojik bileşimleri açısından önemli iken, pH'ın seviyesine göre baskın olan $\mathrm{Fe}^{2+}$ ve $\mathrm{Fe}^{3+}$ iyonlarının ayrıcalıklı rol oynadıkları açıktır. Çözünürlükleri ise daha çok yağış, sıcaklık, nem, pH gibi dış etkenlere bağlıdır.

$\mathrm{Bu}$ çerçevede, drenajın kimyasal nitelikleri bağlamında sülfatlar ve karbonatlar daha etkili olurken, alünit-jarosit grubu kısıtlı çözünürlükleri nedeniyle su kalitesine daha az etki ederler. Zor çözünen ikincil mineral oluşumları drenaj niteliğine etki etmiyor görünse de, drenajın kirlilik yükünü azaltmaları nedeniyle önemlidirler.

\subsubsection{Fizikokimyasal Mekanizmalar}

Cevher üretildikten sonra yapilan tüm iyileştirmelere rağmen satılamayan kalıntıya atık veya artık denilmektedir. Düşük tenörlü olan sülfürlü metalik minerallerden metal kazanıldıktan sonra geriye kalan malzeme miktarı oldukça hacimlidir. Örneğin, günümüzde $\% 1$ 'in altında tenöre sahip porfiri bakır ve altın gibi kıymetli metaller geriye çok pasa bırakırlar. Depolanan yığınlar, cevherin tamamının kazanılması mümkün 
Çizelge 1. Asit drenajında nötürleşme rolü oynayan bazı ikincil karbonat mineralleri [4].

\begin{tabular}{|c|c|c|c|}
\hline Mineral & Formül & Mineral & Formül \\
\hline Kalsit & $\mathrm{CaCO}_{3}$ & Malakit & $\mathrm{Cu}_{2}\left(\mathrm{CO}_{3}\right)(\mathrm{OH})_{2}$ \\
\hline Manyezit & $\mathrm{MgCO}_{3}$ & Azurit & $\mathrm{Cu}_{3}\left(\mathrm{CO}_{3}\right)_{2}(\mathrm{OH})_{2}$ \\
\hline Siderit & $\mathrm{PeCO}_{3}$ & Hidroserüzit & $\mathrm{Pb}_{3}\left(\mathrm{CO}_{3}\right)_{2}(\mathrm{OH})_{2}$ \\
\hline Rodokrozit & $\mathrm{MnCO}_{3}$ & Hidrozinkit & $\mathrm{Zn}_{5}\left(\mathrm{CO}_{3}\right)_{2}(\mathrm{OH})_{2}$ \\
\hline Smitsonit & $\mathrm{ZnCO}_{3}$ & Orikalsit & $(\mathrm{Zn}, \mathrm{Cu})\left(\mathrm{CO}_{3}\right)_{2}(\mathrm{OH})_{6}$ \\
\hline Otavit & $\mathrm{CdCO}_{3}$ & ----- & ------ \\
\hline Gaspeyit & $\mathrm{NiCO}_{3}$ & ----- & ----- \\
\hline Sfaerokobaltit & $\mathrm{CoCO}_{3}$ & ------ & $\mathrm{CaMg}\left(\mathrm{CO}_{3}\right)_{2}$ \\
\hline Aragonit & $\mathrm{CaCO}_{3}$ & Dolomit & $\mathrm{CaMn}\left(\mathrm{CO}_{3}\right)_{2}$ \\
\hline Stronsiyanit & $\mathrm{SrCO}_{3}$ & Kutnoorit & $\mathrm{Ca}(\mathrm{Pe}, \mathrm{Mg})\left(\mathrm{CO}_{3}\right)_{2}$ \\
\hline Viterit & $\mathrm{BaCO}_{3}$ & Ankerit & $\mathrm{CaZn}\left(\mathrm{CO}_{3}\right)_{2}$ \\
\hline Serüzit & $\mathrm{PbCO}_{3}$ & Minrekordit & \\
\hline
\end{tabular}

olmadığından, çok küçük yüzdelerde de olsa sülfürlü mineral içerir ve dolayısıyla, asit maden drenaj1 oluşumuna kaynaklık ve yataklık yapabilirler. Devasa hacimleri dişında, çok bileşenlikleri, suya kısmi doygunlukları, aynı düzey olmayan malzeme yapıları ile birlikte değişken mineralojik içerikleri karakteristik özellikleridir. Bu bakımdan, jeokimyasal, fiziksel ve hidrolojik niteliklerinin belirlenmesi önem taşımaktadır [4].

Üretim faaliyetleri tamamlanmış ve kapatılacak olan maden sahalarında zaten mevzuatın zorunlu tuttuğu önlemler en başından itibaren alınmaktadır. Fakat geçmişte işletilmiş ve cevher bittiğinden veya bir başka sebeple kapatılmış sülfürlü madenlerde yığın yüzeyi, yığını oluşturan malzemenin fiziksel ve mineralojik özellikleriyle, maruz kaldığı atmosferik şartların belirlediği bir biçim kazanır. Yağış etkisiyle bünyesine su alan yığın, yağış ve rüzgar etkisinde aşınır. Ancak, kurak mevsimlerde suyun buharlaşması esnasında bir yandan da yüzeyinden başlayarak giderek katılaşır. Bu dönemlerin tekrarlanmasıyla, yı ğın büyükse, aşınarak tamamen yok olmak yerine, zamanla yüzeyde bir kabuk tabaka gelişir. Kabuk hem oksijen nüfuzuna, hem de su girişine ve dolayısıyla, yığın içindeki süzülmeye mani olur. $\mathrm{Bu}$ durum çok büyük pasa yığınlarının oluşturacağı kimyasal reaksiyonları azaltır ve doğa bir yerde olumsuzluğu kendisi tamir etmiş olur. Üretim faaliyetleri devam eden işletmelerde, yığı̆ üzerine sürekli yeni malzeme depolandığından, bu değerlendirmenin tümüyle farklı yapılması gerekir. Yı̆̆ınla ilgili olarak, fiziksel aktarım süreçleri asıl incelenmesi gereken konudur. Tepkimeleri yönlendiren de yığına oksijen difüzyonu, depolama sirasında getirilen veya yağışla taşınan suyun süzülmesi, yığın içindeki ısının iletilmesi ve gaz hareketleridir (Şekil 8).

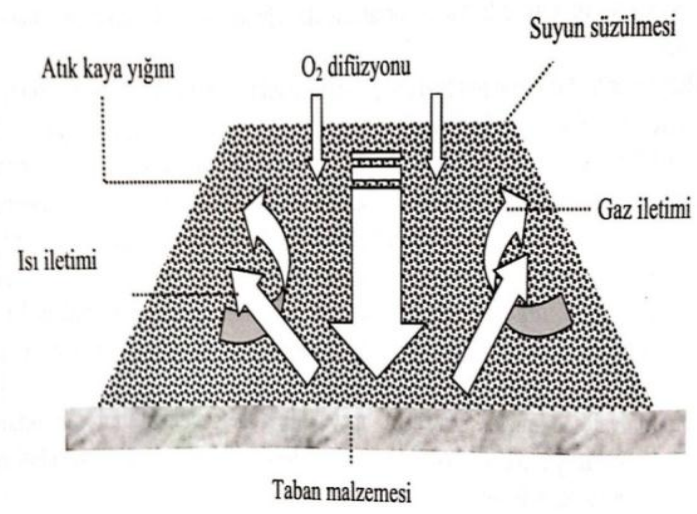

Şekil 8. Yığın içinde etkin olan fiziksel aktarım süreçleri $[18,4]$. 
Asit üreten tepkimelerin ana bileșenlerinden biri oksijendir. Diğer bir deyişle, asit oluşumu oksijenin varlığı ile doğrudan bağlantılıdır. Ayrıca, bakterilerin katalizörlüğü de, bilindiği gibi, oksijen konsantrasyonuyla yakından ilgilidir. Suda çözünmüş halde bulunan oksijenin oksitleyici kapasitesi çok düşük olduğundan, yığın içindeki gaz fazında bulunan oksijen konsantrasyonunun yüksek olması gerekmektedir. Yığınlarda malzeme içindeki boşlukların gaz karışımları üzerinde yapılan çalışmalar, oksijen içeriğinin derinlik arttıkça azaldığına, karbondioksit yüzdesinin arttığına işaret etmektedir [19;4]. Yine de, bazı maden alanlarında $12 \mathrm{~m}$ derinlikte dahi \% 10'dan fazla oksijen bulunabildiği belirlenmiștir. İki ayrı mekanizma oksijen ihtiyacını karşılayabilir (Şekil 9).

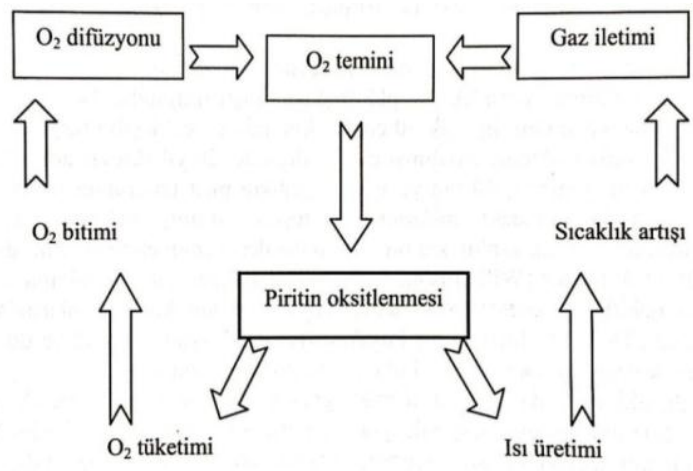

Şekil 9. Yığın içi $\mathrm{O}_{2}$ döngüsü [4].

\subsubsection{Oluşuma Biyokimyasal Etkiler}

Asit maden drenajinda mikroorganizmaların da rol oynadıkları bilinmektedir [20;21;4]. Ancak, asit maden drenajinı meydana gelmesinde mikroorganizmaların-bakterilerin rolü ile mekanizmaların nasıl yürüdüğü uzun yıllar tartışma konusu olmuştur. Görüş birliğine varılmasının önündeki iki büyük engelden biri, tepkimelerde etkili olan bakteri türünün çokluğu ile birlikte bunların farklı davranışları, diğeri ise, deneyler esnasında yalıtılmalarındaki güçlük olarak belirtilmiştir [4]. Madende asit drenajı oluşup oluşmamasında, mikrobiyolojik faaliyetler başlıca rolü oynayabileceği gibi, etkileri ihmal edilebilir düzeyde de kalabilir. Bundan başka süreç hızlı ya da yavaş gelișebilir. Burada, mikroorganizmalar açısından belirleyici olan faktörler; ortamda mevcut türler, türler aras1 ilişkiler, biyolojik aktivasyon enerjisi, organizmaların nüfus (popülasyon) yoğunluğu, büyüme hızları, sıcaklık, bazı organik bileşiklerin (nitrat, fosfat, amonyak vs.) konsantrasyonu, karbon dioksit varlığı, iz element $(\mathrm{K}, \mathrm{Mg})$ varlığ ve bakteriyel inhibitör (yüzey aktif maddeler) konsantrasyonudur.

\subsection{Asidin Nötürlenmesi}

Sülfürlü maden sahalarında gerçekleşen tüm kimyasal, fizikokimyasal ve biyokimyasal tepkimeler asit oluşumuna dönük değildir. Mevcut mineralojik yapı çerçevesinde bir tarafta asit üreten tepkimeler sürerken, diğer taraftan da oluşan asidi tüketen ve neticede ortamı nötürleştiren veya tampon etkisine neden olan süreçler gelişebilir. Drenaj sularının niteliği de, bir anlamda birbirine ters yönde etki eden kuvvetlerin bileşkesi olarak şekillenir.

Sülfürlü demir minerallerinin sebep olduğu asiditenin nötürleșmesinde en etkin mineraller, yerkabuğunda yaygın olarak bulunan karbonat grubu içinde yer almaktadır. Karbonatlarla birlikte silikatlar, oksitler, hidroksitler ve oksihidroksitler nötürleştirme kapasitesine sahip mineral gruplarıdır. Bu minerallerin bir kısmı Çizelge 2' de nötürleştirme kapasiteleri ise Çizelge $3^{\prime}$ de verilmiştir.

Karbonat mineralleri arasında demirli ve manganezli olanları çözündüklerinde, başlangıçta kalsit gibi nötürleştirme etkisi gösterseler de ancak daha sonraki aşamalarda serbest kalan demir ve manganezin oksitlenmesi yüzünden salınan metal iyonlarının hidrolize uğraması ve en sonunda çökelmesi nedeniyle asit üretirler. Ortamı nötürleştirmedikleri gibi, ortamın pH'ını düşürürler.

Kalsit, dolomit ve ankerit türü karbonatların yüksek nötürleştirme potansiyeline karşın, daha yavaş çözünen plajioklaslar ve K-feldspatlar gibi kayaç oluşturan bazı mineraller, karbonatlara 
Çizelge 2. Oluşan asiditeyi nötürleştirme potansiyeli olan bazı mineraller [18].

\begin{tabular}{|c|c|c|c|}
\hline Mineral & Kimyasal Formül & Mineral & Kimyasal Formül \\
\hline Kalsit & $\mathrm{CaCO}_{3}$ & Kaolenit & $\mathrm{Al}_{2} \mathrm{Si}_{2} \mathrm{O}_{5}(\mathrm{OH})_{4}$ \\
\hline Dolomit & $\mathrm{CaMg}\left(\mathrm{CO}_{3}\right)_{2}$ & Albit & $\mathrm{NaAl}_{3} \mathrm{O}_{8}$ \\
\hline Ankerit & $\mathrm{CaFeMgCO}_{3}$ & Klorit & $\mathrm{Mg}_{2} \mathrm{Al}_{2} \mathrm{Si}_{3} \mathrm{O}_{10}(\mathrm{OH})_{8}$ \\
\hline K-Feldspat & $\mathrm{KAISi}_{3} \mathrm{O}_{8}$ & Anortit & $\mathrm{CaAl}_{2} \mathrm{Si}_{2} \mathrm{O}_{8}$ \\
\hline Biyotit & $\left.\mathrm{K}(\mathrm{Mg}, \mathrm{Fe})_{3} \mathrm{Al}, \mathrm{Fe}\right) \mathrm{Si}_{3} \mathrm{O}_{10}(\mathrm{OH}, \mathrm{F})_{2}$ & Olivin & $\left(\mathrm{Mg}, \mathrm{Fe}_{2} \mathrm{SiO}_{4}\right.$ \\
\hline Muskovit & $\mathrm{Kal}_{2}\left(\mathrm{Si}_{3} \mathrm{Al}\right) \mathrm{O}_{10}(\mathrm{OH})_{2}$ & Brusit & $\mathrm{Mg}(\mathrm{OH})_{2}$ \\
\hline
\end{tabular}

Çizelge 3. Bazı Minerallerin Azami Nötürleştirme Potansiyeli [22].

\begin{tabular}{|c|c|c|}
\hline Mineral & Kimyasal Formül & $\begin{array}{l}1 \mathrm{~mol} \mathrm{H}_{2} \mathrm{SO}_{4}{ }^{6} \mathrm{i} \\
\text { nötürlestirmek }\end{array}$ \\
\hline Kalsit & $\mathrm{CaCO}_{3}$ & 1 \\
\hline Dolomit & $\mathrm{CaMg}\left(\mathrm{CO}_{3}\right)_{2}$ & 1 \\
\hline Ankerit & $\mathrm{CaFeMgCO}_{3}$ & 1,25 \\
\hline Klorit & $\mathrm{Mg}_{\mathrm{s}} \mathrm{A} 1_{2} \mathrm{Si}_{3} \mathrm{O}_{1 \mathrm{O}}(\mathrm{OH})_{8}$ & 0,125 \\
\hline Muskovit & $\mathrm{KA}_{2}\left(\mathrm{Si}_{3} \mathrm{AI}\right) \mathrm{O}_{1 \mathrm{O}}(\mathrm{OH})_{2}$ & 0,2 \\
\hline Kaolenit & $\mathrm{A}_{2} \mathrm{Si}_{2} \mathrm{Os}(\mathrm{OH}) 4$ & 0,67 \\
\hline Olivin & $(\mathrm{Mg}, \mathrm{Fe})_{2} \mathrm{SiO} 4$ & 0,5 \\
\hline Homblend & $\mathrm{Ca}_{1.7} \mathrm{M}_{3.5} \mathrm{Fe}_{1.3} \mathrm{AI}_{1.3} \mathrm{Si}_{7} \mathrm{O}_{22}(\mathrm{OH})_{2}$ & 0,11 \\
\hline K-Feldspat & $\mathrm{KAISi}_{3} \mathrm{O}_{8}$ & 0,5 \\
\hline Plajioklas $\left(\mathrm{An}_{\mathrm{o}}\right)$ & $\mathrm{NaAlSi}_{3} \mathrm{O}_{8}$ & 0,5 \\
\hline Plajioklas $\left(\mathrm{An}_{100}\right)$ & $\mathrm{CaAlSi}_{3} \mathrm{O}_{8}$ & 0,25 \\
\hline Götit & $\mathrm{Fe}(\mathrm{OH})_{3}$ & 0,67 \\
\hline Brusit & $\mathrm{Mg}(\mathrm{OH})_{2}$ & 1 \\
\hline Gibs & $\mathrm{Al}(\mathrm{OH})_{3}$ & 0,67 \\
\hline
\end{tabular}

* Mineralin tamamen çözüneceği ve ikincil fazların çökelmeden etkilenmeyeceği varsayılmıştır.

oranla daha güçlü tampon kapasitesine sahip oldukları belirtilmiştir [22].

Minerallerin çözünme kinetiklerine ilişkin yayımlanan araştırmaların sonuçları, büyük değişkenlikler göstermektedir [22]. Çünkü, minerallerin doğadaki çözünürlük değerleri çok sayıda faktöre bağlıdır. Kayaç matriksi içindeki kristal yapıları, tane boyutları, yüzeye açık boşluklar, mineral yüzeyinin şekli (yüzey morfolojisi), yüzeyin bir başka mineralle kaplı olup olmaması, taneciklerin tepkimeye açık yüzey alanları, suyun niteliği ile minerallerin saflıkları ilk akla gelenlerdir. Ayrıca, ortamın fizikokimyasal karakteri de önemli rol oynamaktadır. Örneğin, kalsitin çözünmesinde $\mathrm{CO}_{2}$ kısmi basıncının değişmesiyle, çözünürlük değerinin de değiştiği görülmüştür.

Ortamın pH değeri tepkimeyi ve tepkime ürünlerini belirleyici işleve sahiptir. Kalsit ve dolomitin proton ile reaksiyona girerek bikarbonat katyonunu ürün olarak verdikleri reaksiyonlarda pH 6.3-10.3 aralığında baskın (dominant) nitelikte olduğu belirtilmektedir [23;4].

$\mathrm{CaCO}_{3}($ kat1 $)+\mathrm{H}^{+}(\mathrm{s} 1 \mathrm{v} 1) \longrightarrow \mathrm{HCO}_{3}^{-}(\mathrm{s} 1 \mathrm{v} 1)$ $+\mathrm{Ca}^{2+}(\mathrm{siv} 1)$ 
$\mathrm{CaMg}(\mathrm{CO} 3)_{2}($ kat1 $)+2 \mathrm{H}+(\mathrm{sivl}) \longrightarrow 2 \mathrm{HCO}^{-3}($ sivi $)$ $+\mathrm{Ca}^{2+}(\mathrm{sivl})+\mathrm{Mg}^{+}(\mathrm{sivl})$

Şayet, $\mathrm{pH}$ değeri 6.3'ün altında ise yukarıdaki reaksiyonlar aşağıdaki gibi gerçekleşir ve daha fazla asit nötürleşir.

$\mathrm{CaCO}_{3}\left(\right.$ kati) $+2 \mathrm{H}^{+}$(suda) $\longrightarrow \mathrm{H}_{2} \mathrm{CO}_{3}$ (suda) $+\mathrm{Ca}^{2+}$ (suda)

$\mathrm{CaMg}\left(\mathrm{CO}_{3}\right)_{2}$ (kat1) $+4 \mathrm{H}^{+}$(suda) $\rightarrow 2 \mathrm{HCO}_{3}$ (suda) $+\mathrm{Ca}^{2+}($ suda $)+\mathrm{Mg}^{2+}$ (suda)

Karbonat minerallerine kıyasla çözünme hızları, özellikle nötür $\mathrm{pH}$ civarında yavaş olan silikatların çözünürlükleri pH'ın düşüşüyle artar. Hatta bazı silikatların nötürleştirme kapasiteleri de karbonatlardan yüksektir. Fakat, çözünme hızlarının yavaşlı̆̆ etkinliklerini azaltmaktadır. Çünkü tamamen çözünmeleri ya çok uzun zaman almakta, ya da hiçbir zaman gerçekleşmemektedir.

İkincil mineral oluşumları, asit oluşumunda olduğu gibi, asidin nötürleşmesinde de kayda değer etki yapabilme yeteneğine sahiptir. $\mathrm{Bu}$ mineraller arasında tek veya çift karbonat içerenler ağırlıktadır.

Birincil kalsit, ortoklas ve gibs gibi mineraller, özellikle $\mathrm{pH}$ düştüğünde çözünerek ortama iyon salarlar ve dengeye erişinceye dek bu tepkimeler devam eder. Dengeye erişim sonrasında çözünme tepkimesi tersine dönerek ikincil mineral oluşumları gerçekleşir [24;4]. Öte taraftan, $\mathrm{Fe}^{3+}$ dışında bir oksitleyici ile tepkimeye girdiklerinde, çözeltinin metal yükünü arttırıp, asiditeye etkileri olmayan $\mathrm{Cu}, \mathrm{Pb}$ ve $\mathrm{Zn}$ cevherlerinin oksitlenmesi neticesinde, karbonatlı hidroksitler (hidroserüzit, hidrozinkit ve orikalsit gibi) meydana gelir. Bunların tekrar çözünmesi de, $\mathrm{OH}^{-}$ve $\mathrm{CO}_{3}^{2-}$ iyonlarının salımına bağlı olarak, ortam $\mathrm{pH}^{\prime}$ ının yükselmesi yönünde bir tesir yaratır.

\subsection{Asit Maden Drenajının Nitelikleri}

Madencilik faaliyetlerinden etkilenen suların nitelikleri iki temel sebeple belirlenmek durumundadır. Birincisi, suların maden alanını terk ettiğinde taşıdığı özellikler, onun alıcı ortam üzerindeki etkilerinin ne olacağını belirler. İkincisi, suyla ilgili uygulanacak (tesiste su kullanımı ve alıcı ortama boşaltma) çözüm yöntemleri ve çevresel açıdan gerekli yönetim modelleri suyun nitelikleri ile doğrudan bağlantılıdır. $\mathrm{Bu}$ noktadan hareketle, suyun niteliklerini ortaya koyan parametrelerin anlık ve dönemsel bazda hem tanımlanması, hem de miktarlarının saptanması önem taşımaktadır [4].

Madenlerin çeşitliliği bir yana, aynı tür maden yataklarının, örneğin sülfürlü metalikler gibi, jeolojik ve mineralojik yapılarının her bir sahada farklılık göstermesi, madenlerin bulunduğu bölgelerin coğrafik karakterlerinin (iklim, topografya, hidroloji vs.) güneyden kuzeye doğudan batıya değişken olması drenaj sularının fiziksel, kimyasal ve biyolojik niteliklerinin her bir saha için, benzerlikler taşısa bile, farklı olması sonucunu getirir. Genel manada madencilik faaliyetlerinden etkilenen suların karakteri belirlenirken beş ortak parametre üzerinde durulmaktadır. Bunlar; pH, demir dışı ağır metal konsantrasyonu, $\mathrm{Fe}-\mathrm{Al}$ konsantrasyonu, anyon içeriği (bilhassa $\mathrm{SO}_{4}^{2-}$ ) ile toplam askıda katı madde miktarının uzantısı olan bulanıklıktır (türbidite). Ayrica, asidite, mineral asidite ve organik asidite de, kimi araştırmacıların dikkate aldığı parametrelerdir.

$\mathrm{pH}$ nadiren yüksek bazik değerlere ulaşsa da asidik özellikte ve genellikle 8 'den daha düşük değerlerdedir. Sıfıra bile yaklaşılan çok asidik özellikler belirlenmiştir. Farklı pH derecelerine göre asidik kaya drenajı, nötür maden drenajı ve tuzlu çözelti drenajı diye Şekil 7'de verilen durumlarda drenaj gelişmektedir.

$\mathrm{Fe}$ ve $\mathrm{Al}$, görsel etkilere/demir şapkalar ve sizıntılarla formasyonların renklenmesine sebep olmaları (renkleri sarıdan turuncuya, kahverenginden kırmızıya kadar değişen hidroksit çökelleri) ve ağır metal davranışında yönlendirici konumları dolayısıyla dikkate alınmaktadır. Sülfürlü cevherlerin asidik suyla temasında çözünmeleri, drenaj sularında sıklıkla yüksek konsantrasyonda sülfat iyonu oluşturur. Ayrıca bazı durumlarda $\mathrm{pH}$ 'ın 8'e ulaştığı durumlarda da yüksek sülfat konsantrasyonu görülebilmektedir. 
Askıda katı taneciklerinin ana kaynaklarından biri demirdir. Fe pH'daki değişimlere göre katı madde olarak veya iyon halde bulunabilir. Yine daha sınırlı düzeyde alüminyum da benzer davranış gösterebilmektedir. Meteorik ayrışım olayları ve aşınmalar ile cevher hazırlama-zenginleştirme işlemleri gereği uygulanan ögütmeler sonucu çok ince boyuta indirilen (şlam) malzeme suda yavaş çözünen veya çözünmeyen bir bileşime sahipse (silikatlar gibi), bunlar laminer olmayan akış rejimlerinde kolaylıkla çökelememekte ve uzak mesafelere taşınabilmektedir.

Asit maden drenaj1 genel anlamda madenlerden etkilenen sular ile belirli kıstaslarda bazı benzerlikler taşır. Ancak, doğal olarak bu tür suların niteliklerinin saptanmasında kullanılan başka parametreler bulunmaktadır. Fe-Al, sülfat, ağır mineral konsantrasyonları ve $\mathrm{pH}$ ortak olmakla beraber $\mathrm{Mn}, \mathrm{Fe}^{2+}$ ve $\mathrm{Fe}^{3+}$ konsantrasyonları ile asidite değerleri önemli göstergelerdir.

\subsection{Asit Maden Drenajının Çevresel Etkileri}

Asit kaya/maden drenajı asidik özellikte olup $\mathrm{pH}$ değeri genellikle 5' in altındadır. Önceki bölümlerde ayrıntılarıyla görülen kimyasal reaksiyonlarda vurgulandığ 1 gibi başlıca oksitlenme reaksiyon ürünleri arasinda sülfat ve proton iyonları bulunmaktadır. Ortamda $\mathrm{H}^{+}$ve sülfat iyonları varsa sülfürik asit hemen oluşmaktadır. Oluşan çözeltiler içinde ya da mevcut ortamda metal, ağır metal konsantrasyonu yüksek olabilir. Bunlardan başka yüksek konsantrasyonlarda askıda katı madde de vardır. Drenaj sularında organik içerik çok düşük ve pH'da 8'den daha küçük değerlerdedir. Eğer, bir maden işletmesinde asit drenaj oluşması potansiyeli varsa ve gereken tedbirler alınmazsa, muhtemelen drenajın gelişimiyle bazı çevresel etkilerle karşı karşıya kalınması kaçınılmazdır. Drenajdan en fazla etkilenecekler ise yüzey ve yeraltı suları ve basenlerdir (göller, kapalı denizler).

Asit kaya/maden drenajı oluştuğunda ne türden sonuçlar doğurur? Asit maden drenaj1 yüzey akıntıları, yağmur suları, sızma ve süzülmeler yoluyla taşınarak nehirlere, göllere ve yeraltı su sistemlerine karışabilir. Böylelikle, su kalitesi değişime maruz kalır, kirlenme gerçekleşir. $\mathrm{Bu}$ bağlamda, alıcı ortamlarla bağlantılı ekosistemler etki altına girebilir. Neticede, türlerin yok olması, besin zincirinin basitleşmesi ve ekolojik duraylılığın azalması görülebilir.

Yapısal karmaşıklığı nedeniyle, drenajın her bir parametresinin tek başına ele alınması yanıltıcı olabilir. Bu noktadan hareketle, çevresel etkilerin daha iyi anlaşılabilmesi için etkiyi yaratan faktörlerin rolünü irdelemek, aralarındaki ilişkilere bakmak, etkilerini gruplandırmak ve nihayet, ortaya çıkabilecek sonuçları bütününde değerlendirmek gereklidir.

Öte yandan, etkinin boyutlarını tespit edebilmek amaciyla su kalitesi incelenirken fiziksel, kimyasal, fizikokimyasal ve biyokimyasal ölçüm, test ya da analizlerin dişında, suda yaşayan canlıların $\mathrm{pH}$, metal konsantrasyonu türünden parametrelere duyarlılıklarından da yararlanılabilmektedir.

Balık türleri ve sistemdeki nüfusları önemli kirlilik göstergeleri arasındadır. Ancak, balıkların hareketli yaşam biçimleri, sıkça yer değiştirmeleri çalışmaları güçleştirmektedir. Suların en alt kısımlarında yaşayan makroomurgasızlar (macroinvertebrate) ise sinırlı hareketlilikleri, göreceli olarak aynı mevkii de uzun süre kalmaları ve kirleticilere karşı değişen duyarlılıkları nedeniyle su kalitesinin tespit edilmesinde etkin olarak kullanılırlar.

\section{ASIT KAYA/MADEN DRENAJI İÇIN SAHA KARAKTERIZZASYONU VE KESTIRIM ÇALIŞMALARI}

İncelenen maden sahasının gerek işletme ve gerekse işletme sonrası asit kaya/maden drenaj1 oluşturup oluşturmayacağı hakkında bilgi sahibi olmak ve önceden kestirim/öngörüde bulunabilmek için çok ayrıntılı saha çalışmasına ve sahadan alınan yan kayaç ve cevher örnekleri üzerinde mineralojik-kimyasal incelemelerin de titizlikle yapılmas1 zorunludur. Asit maden drenaj1 
bir sorun olduğuna göre bu sorunu hiç meydana gelmeden önlemek veya bu aşama geçilmişse, güvenli ve ekonomik şartlarda bertaraf edebilmek, daha öncesinde bazı adımları atmayı gerekli kılar. Çünkü dünyada 50 yıldır uygulanan ve sıkı bir şekilde denetlenen risk analiz yöntemleri 20 yıldır da ülkemizde uygulama alanı bulmuş olup, her geçen gün de denetimler sıklaştırılmaktadır. Yapılan tüm faaliyet alanlarında bir sorunun çözümü birkaç adımlık basit bazı işlemler dizisinden ibaret olabileceği gibi, çözüm için karmaşık süreçlerden oluşan uzun bir yol haritasına da ihtiyaç olabilir. En basitinden en zoruna kadar her sorunun çözümü, sebebinden başlayarak doğurabileceği sonuçlara kadar, onun yeterince anlaşılmasıyla başlar. Ancak ondan sonra, konuya ilişkin bir planlama yaparak, birbirini takip eden aşamaların gerektirdiği kararları vermek ve uygulamakla istenen nitelikte bir çözüme ulaşmak mümkündür.

Madencilik faaliyetleriyle ortaya çıkması muhtemel çevresel sorunlar açısından da benzer durumlar söz konusudur. Madencilikle ilgili vurgulanması gereken en önemli husus madenciliğin doğal işlemler sebebiyle biraz daha farklı olduğudur. Çünkü maden yataklarının birbirinden çok farklı özellikler sunması aynı madenin farklı kotlarında bile önemli ayrıcalıkların görülmesidir. Bu yüzden diğer sektörlerin aksine, maden işletmelerinde genellemelere gitmek ve aynı paralelde bir çıkış yolu bulmak her zaman mümkün olamaz. Asit kaya/maden drenajı özel olarak ele alındığında bazı görüşlere göre, "herhangi bir maden alanında piritin, hatta bir sülfürlü mineralin mevcudiyeti sahayla bağlantılı suların asitlenmesi için yeterlidir", aksi bir görüşe göre ise, "karbonat minerallerinin varlığı asit oluşumunu kesinlikle önler". Maden alanına ait etraflı bir tespit ve değerlendirme çalışması yapmaksızın, yalnızca sülfür ve karbonat minerallerinin varlıklarının tespitine dayalı olarak, bu iki görüşten biriyle cevap vermek bilimsellikten uzak bir davranıştır. Morin ve Hutt [25] yaptıkları bir değerlendirmede "Maden alanı bileşenleri birbirleriyle ve aynı şekilde açık çevreyle etkileşim içindedir. $\mathrm{Bu}$ ortam, bileşenlerin bünyesine girebilen veya onları terk edebilen kat1, s1v1 ve gaz fazlarından oluşur. Sonuç olarak, klasik teknik manada, her maden sahası bileșeni ve maden sahasının kendisi izole sınırları bulunmayan açık sistemlerdir. O nedenle, bu açık sistemler, tüm ortam ve onun fiziksel, kimyasal ve biyolojik karakterleri doğru bir şekilde bilinmediği takdirde, tanımlanamaz ve önceden kestirilemez" denmektedir $[25,4]$.

Kestirim veya öngörünün yapılabilmesi için bir dizi incelemenin mutlaka bu konuda deneyimli mühendis veya araştırıcılar tarafindan yapılması gerekli olup bu çalışmalar için yapılan projelere de yeterince finansal destek sağlanmalıdır. Maden yatağının aranıp bulunmuş maden haline getirilerek ekonomikliğine karar oluşturulmuş ise zaten temel jeolojik araştırmalar, arama faaliyetleri sırasındaki jeokimyasal tetkikler sahaya ilişkin önemli bilgiler vermiş demektir. Arama sırasında etütler için önceden açılmış galeriler, kazılan arama kuyuları, yarmalar ve çukurlardan alınan örneklerin kimyasal, mineralojik analizleri ve jeoteknik testleri ile daha çok rezervi, cevherin yataklanma biçimini, örtü tabakası kalınlığını vs. belirlemeye yönelik sondaj karotlarının aynı şekildeki analizleri, madencilik açısından, sahanın niteliklerini büyük ölçüde ortaya çıkarır. Yine, madencilik faaliyetlerine geçilmesi öncesinde yeraltı ve yerüstü su durumunu, mevcudiyet ve nitelik bakımından tespit amacıyla yapılan araştırmalar ile Çevresel Etki Değerlendirmesi (ÇED) aşamasında yürütülen kapsamlı ve çok yönlü (jeolojik, biyolojik, hidrolojik coğrafik ve benzeri) incelemeler saha çalışmalarıly elde edilecek verilerin neredeyse tamamı saha çalışmaları içinde değerlendirilmektedir.

Saha çalışmaları, numune alma işlemleri ve alınan numuneler üzerinde gerçekleştirilecek deney ve testler için bugün dünyanın gelişmiş ülkelerinde kullanılan yüzlerce yöntem bulunmaktadır. Asit kaya/maden drenajının kestiriminde değerlendirmeye alınan temel parametreler asit üreten sülfürler ile birlikte başta karbonatlar olmak üzere, asit oluşumuna engel olan ya da ortamı nötürleştiren silikatlar ve diğer nötürleştirici minerallerin olup olmadığıdır. Bunun için sülfürlerin ve nötürleştirici mineral içeriklerinin belirlenmesi gerekmektedir. Elbette ki, asit maden drenajı sürecini etkileyen ve örtü tabakası, artık 
yığını, pirit stokları gibi oluşuma kaynaklık eden kütlelerin kimyasal, fiziksel, fizikokimyasal ve biyokimyasal özelliklerini tayin eden parametrelerin de örneklemede dikkate alınması büyük önemi haizdir. Bunları sıralamak gerekirse; tane boyut dağılımı, gözenekliliği, su geçirgenliği, nem muhtevası, yığın ve tane yoğunlukları, metal içerikleri ve bakterilerin varlığı sayılabilir. Numune alımı katılarla sınırlı değildir. Yeraltı ve yerüstü su sistemleri ve tabiatıyla drenaj suları da mutlaka örneklenmek durumundadır.

Maden sahası için asit maden drenajı potansiyelinin ve drenaj niteliklerinin kestirilmesinde kullanılacak olan kimyasal, fiziksel, mineralojik ve biyokimyasal veriler üretilir. Eğer maden zaten işletilmekte olan bir maden ise üretime ilişkin kayıtlar ile asit oluşumuna kaynak teşkil edebilecek potansiyel noktalarla yı̆̆ınlara ait çoğunlukla gözleme ve yerinde (in-situ) ölçümlere dayalı bilgiler oluşturulmalıdır. Böyle bir maden sahası için oluşturulmuş sorun ve çözüm algoritması Şekil 10 'da verilmiştir.

\subsection{Asit Maden Drenajı Potansiyelinin ve Drenaj Niteliğinin Kestirimi}

Kestirim asit kaya/maden drenaj1 potansiyelinin olup olmadığının, varsa büyüklüğünün, sürekliliğinin, çevreye metal salımlarının ve uzun dönem etkilerinin değerlendirilmesini kapsar. Kestirim için kullanılmakta olan yöntemler arasında jeokimyasal statik ve jeokimyasal dinamik (kinetik) testler, jeokimyasal modellemeler, liç (özütleme) testleri, jeoistatistiksel modellemeler (3D modelleme), saha ve laboratuvar çalışmalarıyla sağlanan verilerin değerlendirilmesi ve yorumlanması sayılabilir. Ayrıca, benzer özellikler gösteren başka maden alanlarındaki artık malzeme ile ilgili gelişmelerden (gözlem ve izleme) edinilen veriler de çalışmalarda kullanılmaktadır [4]. En sık başvurulan metotlar arasındaki jeokimyasal statik testler, örneklenen sahaların asit üretme potansiyelleriyle üretilebilecek asidi nötürleştirme potansiyelleri arasındaki cebirsel farkın veya oranın sonucunda bulunan değerin yorumuna dayalıdır. Büyük ölçüde kimyasal ve mineralojik analizler ile basit testlere dayalı olup; uygulama kolaylıkları, düşük maliyetleri ve kısa sürede netice vermeleri münasebetiyle tercih edilirler. Bunun aksine, jeokimyasal kinetik testlerden sonuç alınması uzun sürmektedir. Fakat doğal koşulların laboratuvar ortamında benzeştirilmesi esas alındığından, statik testlere kıyasla daha güvenilir değerler elde edilmektedir. En kısa süre zarfında sonuç almayı hedefleyen matematiksel modeller ise, asit drenaj oluşum mekanizmalarını birtakım varsayımlara dayanarak basite indirger. Ancak, süre ve maliyet azalırken, güvenilirlik de azalmaktadır. Kullanımları henüz yaygın olmayıp, gelişme sürecinde oldukları söylenebilir.

Bir numunenin asit potansiyelinin tayininde kullanılan üç temel uygulamadan bahsedilebilir. Bunlar;

- Azami potansiyel asiditenin hesaplanmasında, toplam S 'nin saptanması ve piritin oksitlenmesi için geçerli stokiyometrik eşitliğin kullanılması,

- Demir oksitlerin uzaklaştırılmasının ardından, piritle bağlantılı demirin tespit edilmesi ve yine, piritin oksitlenmesi için geçerli stokiyometrik eşitlik kullanılarak potansiyel asiditenin hesaplanmas1,

- Numunenin kuvvetli bir kimyasal oksitleyiciyle (hidrojen peroksit gibi) muamele edilmesi veya şiddetli bozuşturma sonrasında asit titrasyonu uygulanmasidir.

Önceki başlıklarda da belirtildiği gibi asit üretme potansiyeli ile asit nötürleştirme potansiyeli değerlerinin bulunmasından sonra, iki değer arasında bir matematiksel işlemle NNP (net nötürleştirme potansiyeli) veya NAÜP (net asit üretme potansiyeli) kalsiyum karbonat eşdeğeri cinsinden (sahadaki malzemenin tonu başına $\mathrm{kg}$ $\mathrm{CaCO}_{3}$ veya $\mathrm{kg} / \mathrm{t} \mathrm{CaCO}$ olarak) hesaplanmış olur. Matematiksel işlemin ortaya koyduğu rakamsal değer, karar verme açısından, yalnız başına yeterli olamaz. Burada esas olan, elde edilen değerin sağlıklı yorumlanabilmesidir. Gerçekten de yorumlama ciddi zorluklar taşımaktadır. Yalnızca elde edilen değerlerden yola çıkarak yapılan yorumun çok güvenilir olacağı şüphelidir. Şüpheleri asgari seviyeye indirmek için, test sonuçlarıyla birlikte, madencilik öncesi şartlar, su 


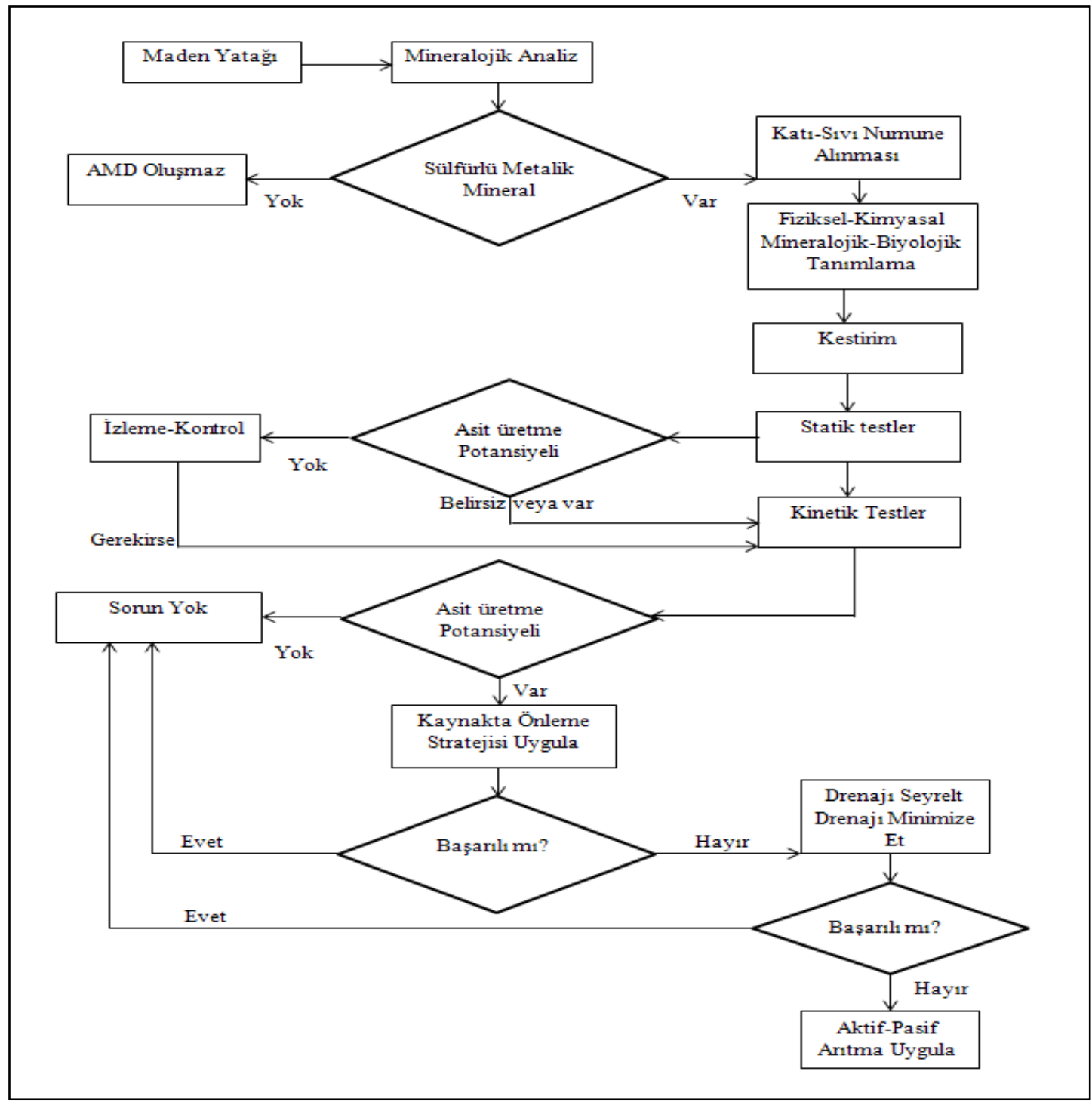

Şekil 10. Asit maden drenajı sorununda çözüm algoritması [4].

kalitesi, yeraltı ve yerüstü su sistemleri, stratigrafi, litoloji, atmosferik etkiler, düşünülen madencilik uygulamaları ve başka madenlere ait kayıtlar dikkate alınmak durumundadır.

\subsection{Asit Maden Drenajı Potansiyelinin ve Drenaj Niteliğinin Statik Yöntemlerle yapılan Kestiriminde Hata Kaynakları}

Gerek asit üretme ve gerekse üretilen asiti nötürleştirmede oluşacak karbonat potansiyelinin hesaplanmasında kullanılan yöntem ve saha özelliklerinden kaynaklanan bazı hatalar kaçınılmaz olup bunların minimize edilmesi gerekir. $\mathrm{ABH}$ yöntemlerinin parametreleri işlem süreçleri tane boyutu, kullanılan asidin türü, değerlendirilen S içeriği, süre ve sıcaklık gibi bazı değişkenler açısından farklılıklar göstermektedir. $\mathrm{Bu}$ durumun doğal neticesi olarak da mevcut yöntemlerin; basitlik, süre ve ekonomi bakımından 
bazı zaafları, birbirlerine kıyasla avantajlı ve dezavantajlı yanları bulunmaktadır [26]. Testlerin güvenirlikleri yönüyle böyle bir değerlendirme ise, sağlıklı değildir. Çünkü saha koşullarıyla uyumluluk gibi, güvenirliği belirleyen başka unsurlar söz konusudur.

Numunenin asit üretme potansiyeli tayin edilirken, araştırmacıların genel anlamda üzerinde hemfikir oldukları kabuller çerçevesindeki hatalar bir kenara bırakılacak olursa, konu S ile sınırlanmış olur. $\mathrm{S}$ değeri: Asit üretme potansiyelinin bulunmasında ister toplam $\mathrm{S}$, isterse sülfitli minerallere bağlı S dikkate alınsın, her iki halde de sülfürlerin tamamen çözüneceği kabul edilmektedir. Doğal ortamda \% 100 çözünmenin son derece güç, hatta imkansız olduğu ortadadır. Dolayısıyla, statik testlerde verilen değer potansiyelden ibarettir. Burada, asit üretme potansiyeli açısından asıl önemli nokta, hesaplamalarda temel alınan S'lü minerallerdir.

Mineraller S'ü ya sülfitler $\left(\mathrm{CuS}, \mathrm{ZnS}, \mathrm{PbS}, \mathrm{FeS}_{2}\right.$, $\mathrm{MoS}_{2}, \mathrm{Sb}_{2} \mathrm{~S}_{3}, \mathrm{As}_{2} \mathrm{~S}_{3}, \mathrm{CU}_{3} \mathrm{AsS}_{4}$ vs.) veya sülfatlar $\left(\mathrm{KAl}_{3}\left(\mathrm{SO}_{4}\right)_{2}(\mathrm{OH})_{6}, \mathrm{BaSO}_{4}, \mathrm{PbSO}_{4}, \mathrm{CaSO}_{4} .2 \mathrm{H}_{2} \mathrm{O}_{2}\right.$, $\mathrm{SrSO}_{4}, \mathrm{CaSO}_{4} \quad$ vs.) halinde bünyelerinde bulundururlar. Kömür yataklarında yaygın ve karbonatlı kayaçlarda daha az olarak organik $\mathrm{S}$ bulunması olağandır. Bilindiği gibi toplam kükürt aşağıdaki eşitlikle hesaplanmaktadır.

Toplam \% S = \% Sülfidik S + \% Sülfat S + $\%$ Organik $\mathrm{S}$

Toplam S değeri ile hesap yapıldığında, sudaki ya da çözücü ortamdaki çözünme davranışları göz ardı edilerek, tüm S 'ün aside kaynaklık edeceği varsayılmaktadır. Oysa metal sülfürler ortam şartlarının etkisiyle zaman içinde yavaş bir hızda bozuşmaya uğrayarak çözünür. Fakat bilindiği üzere, mineraller oluşum tane boyutu, kristal yap1 ve büyüklüğü ile mineral bileşimi ve iz element içeriği bakımından farklılıklar arz ederler. $\mathrm{Bu}$ da, doğal olarak sülfürlü cevher minerallerinin bozuşmaya (oksitlenmeye) karşı direncinin değişken olması sonucunu doğurur [27; 4].

Öte yandan numunelerin asit nötürleştirme potansiyelleri tayin edildiğinde, farklı değerlere ulaşılabildiği bilinmektedir. Oysa, asit üreten ve oluşan asidi tüketen veya tampon etkisi gösteren minerallerin varlığında, gerçek birer asit üretme ve nötürleştirme potansiyelleri olması gerekir. Efektif veya ampirik olarak da adlandırılan gerçek nötürleştirme potansiyeli sahaya özgü çevresel şartlara, mineralojiye, tane boyutuna ve minerallerin çözünme tepkimelerinin hılarına bağlıdır. Efektif nötürleştirme potansiyeli (ENP), belirli mineraloji, tane boyutu, mineral tepkime hızları ve sahaya özgü çevresel koşullar altında bir numunenin ortam pH'ını 6 veya daha üzerine çıkarma kapasitesi olarak tanımlanmaktadır. Farklı yöntemlerin aynı numuneye uygulanmasıyla, birbirlerini tutmayan sonuçlar elde edilmesi, işlemlerin bazı hatalar içerdiğini göstermektedir. Diğer bir ifadeyle, "ENP değerine yaklaşıldığı oranda, statik testin güvenirliği artar" denebilir.

Statik yöntemlerin sonucunda gerekli görüldüğünde başvurulan jeokimyasal kinetik testler, temelde doğada gerçekleşen süreçlerin, olabildiği ölçüde, benzeştirme yoluyla laboratuvar koşullarına taşınmasıdır. Ancak, in-situ niteliğinde, bizzat sahada gerçekleştirilen kinetik testler de mevcuttur. Kinetik testlerde numuneler özütlenir (leaching), özütler (leachates) düzenli aralıklarla toplanir ve analiz edilir.

Statik testlerin, büyük oranda kabullere ve hesaplamalara dayanması sebebiyle, teorik olduğu söylenebilirse de, NP'nin sinırlı kimyasal tepkimelerle ortaya konması bakımından, kısmen ampirik özellikler taşıdığı kabul edilebilir. Bu anlamda tamamen statik sinırlar içinde kalmaz. Kinetik testler ise; kimyasal, fiziksel ve biyolojik sistemleri ve süreçleri birleştirirken, tepkime kinetiklerini, hızlarını ve mekanizmalarını çözümlemeyi amaçlar. Kinetik testler, bu esaslara göre tasarlanır ve yürütülür. Bir başka deyişle, benzeştirme temelli deneyselliği ile de ampiriktir.

Kinetik testlerin geliştirilmesi ve uygulanmasına yönelik araştırma ve çalışmalar, ağırlıklı olarak kömür artıkları ve örtü tabakaları üzerinde olmak üzere, sonraki y1llarda da, hem saha hem de laboratuvar kapsamında yaygınlaşarak devam etmiştir. Bunu, metalik sahaların asit drenaj üretim potansiyellerinin kestirimlerini içine alan kinetik 
test araştırmaları izlemiştir. İşlemler ve kullanılan donanımlar açısından kayda değer kimi farklılıklar gözlenmişse de, testlerin ilkeleri bakımından köklü değişiklikler olduğu söylenemez. Buna karşın; Nem hücreleri, Kolonlar, Soksolet Ekstraktör, BCAD, Çalkalama (Shake Flask), Yaş-Kuru Döngü (Wet-Dry Cycle), Yüksek Sicaklık Testi gibi laboratuar ile Küvet (Tubs) ve Test Yı̆̆ını gibi arazi kapsamlı çok sayıda kinetik test yöntemi uygulanır olmuştur.

\section{SONUÇLAR}

Asit Kaya (Maden) Drenajı kavramı çok uzun yıllardır gelişmiş ülkelerde kullanılmasına rağmen en fazla son 20 yıldır ülkemizde de uygulamaya konulmuş ve özellikle büyük alanlarda açık işletme yöntemiyle üretilecek ve parajenezlerinde başta pirit, pirotin ve markazit gibi sülfürlü mineraller içeren maden yataklarının ÇED raporlarında bu konunun iyice araştırılması istenmektedir. Anadolu'nun bir çok yerinde çoğu hidrotermal damarlar şeklinde görülen ve genellikle yeraltı yöntemiyle işletilen $\mathrm{Pb}-\mathrm{Zn} . \mathrm{Cu}$ madenlerinde asit kaya (maden) drenajları konusunun çevresel açıdan büyük sakıncalar oluşturmamasına karşılık son 15 y1l içinde büyük önem kazanan ve oldukça geniş alanlardaki altın içerikli maden sahaları için bu konu sıkıntılar yaratmaktadır. Açılan açık işletmelerin çok büyük hacimde dekapaş ürünü örtü kalıntısının ve oluşan açık işletme şevlerinin duyarlılık sorunlarına bir de asit üretecek sülfürlü minerallerin olup olmadığ $\breve{1}_{1}$ sorgulanmaktadır. Ayrıca altın üretiminden geriye kalan artık ve atıklar oldukça geniş hacimler oluşturduğundan bunların içindeki sülfürlü minerallerin atmosferik etkilenmeler sonunda oluşturacağı asiditenin toprak ve yeraltı-yerüstü su kaynaklarını kirletme olasılıklarının güvenilir yöntemlerle daha ÇED safhasında belirlenmesi gerekmektedir.

Sülfürlü parajenez içindeki bilhassa demirli olanlarının atmosferden gelen rutubet ve oksijenle bozuşarak önce sülfat formuna geçerek ortama asit vermesinden sonra bir dizi fizikokimyasal reaksiyonları başlatmasıyla asit drenajı başlamakta ve gerek parajenezdeki öteki sülfür minerallerin varlığı ve içinde bulunduğu kayacın mineralojik bileşimine göre oldukça kopleks dönüşümler oluşmaktadır. Parajenezinde sülfürlü mineraller bulunan (pirit, pirotin ve markazit başta) açık ve kapalı maden işletmelerinin asit drenajı üretip üretmeyeceğinin belirlenmesi için herşeyden önce saha karaktirizasyonun doğru bir şekilde yapılması gerekmektedir. Sahanın çok ayrıntılı uygun ölçekli jeolojik, hidrojeolojik ve tektonik haritasının çıkarılması ve çok sayıda sondaj loğlarına dayanılarak cevher içeren zonların blok diyagramda görülebilir hale getirilmesi zorunludur. Gerek cevherleşmenin üst zonlarından ve gerekse sondaj karotlarının cevher kesen kısımlarından hazırlanan ince ve parlak ksitlerle kimyasal ve mikroprop analizleri dikkate alınarak yatağın parajenezi belirlenmeli ve bu parajenez içinde asit oluşturabilecek minerallerin oranları geliştirilmiş birçok statik ve kinetik jeokimyasal diyagramlarla incelenmelidir. Daha sonra ise yankayacın mineralojisi belirlenerek oluşması muhtemel asidin doğal ortamda nötürleştirilip nötürleştirilemeyeceği saptanmalıdır. Yapılacak bir dizi inceleme sonunda hangi yöntemlerin verilen bu maden sahası için daha az hatalı yaklaşım olacağına karar verilerek çeşitli testler uygulanarak veri tabanları oluşturularak saha verileri, test sonuçları benzer madenlerde alınan sonuçları da dikkate alarak kestirimlerde (öngörülerde) bulunulacaktır. $\mathrm{Bu}$ işlemlerin oldukça pahalı olduğu ve hem maden işletmeye geçmeden, hem işletme sırasında ve hem de maden kapandıktan sonra testlerin titizlikle uygulanması zorunluğu madencileri memnun etmemektedir. Ancak ülkemizde henüz pek fazla uygulanmadığı için henüz konunun önemi benimsenmemiş olsa da gerek toprak kirlenmesi ve çevreye verilen zararların boyutlarına göre açılacak kamu davaları veya işletmeden zarar gören gerçek kişilerin açacağı tazminat davaları daha büyük maddi kayıplara sebep olduğu unutulmadan asit maden drenajına gerektiği kadar önem verilmesi sürdürülebilir bir madencilik sektörü için zorunlu görülmektedir.

\section{KAYNAKLAR}

1. Paine, P.J., 1987. "An Historic and Geographical Overview of Acid Mine 
Drainage", In Proceedings: Acid Mine Drainage Seminar/Workshop, Conservation and Protection Environment, Ontario, Canada, pp. $1-45$.

2. Skousen, J.G., 1996. "Acid Mine Drainage", "Acid Mine Drainage Control and Treatment (Compiled by J.G. Skousen and P.F. Ziemkiewicz), W. V. Univ. And N. M. L. R. C. Pp9-12.

3. Callaghan, 1998. in Bernard, A.J. 1971. Recyclage Metallogenie Tome I, II, III Ecole de Geologie de Nancy-France.

4. Karadeniz, M., 2008, Sülfürlü Madenlerin Sorunu Asit Maden Drenajı ve Çözümü, MMO Yayını, 231 s, Ankara.

5. Gray, N.F., 1997. "Environmental Impack and Remediation of Acid Mine Drainage: A Management Problem",Environmental Geology, 30, (1/2), March, s. 62-71.

6. Garrels, R.M., 1953. Mineral species as functions of $\mathrm{pH}$ and oxidation - reduction potentials, with special referenceb to the zone of and secondary enrichment of sulfide ore deposits : Geochim. Cosmoschim- Acta, 5, 4, 153-158.

7. Yolcubal, İ., 2008. Çevre Jeolojisi, Ders Notları, Kocaeli Üniv. Jeoloji Böl., Kocaeli.

8. British Columbia Task Force, 1989. "Draft Acid Rock Drainage Technical Guide", S. Robertson and Kirsten Inc., Vancouver, British Columbia, Canada, August.

9. Çevikbaş, A., 1991. Ulukışla-Çamardı (Niğde) Tersiyer Havzasının Jeodinamik Evrimi ve Maden Yatakları Yönünden Önemi. Doktora Tezi, İ.Ü. Müh. Fak. Jeoloji Müh. Böl.,235 s.(Yayınlanmamış), İstanbul.

10. Akyıldız, M., 1999. Pozantının (Adana) Doğu (Akdağ ve Kuzeydoğusunda (Karıncadağ) yüzeyleyen kurşun-çinko yatakları, Ç. Ü. Fen Bilimleri, Enst., Doktora Tezi, 189 s.

11. Akyıldız, M., Anıl, M., 1999. Pozantının (Adana) Doğu (Akdağ) ve Kuzeydoğusunda (Karıncadağ) Yüzeyleyen Çinko-Kurşun Cevherleşmesinin Minerolojisi. ÇÜ Müh. Mim. Fak. Dergisi Cilt 14 Say 1-2, S 103-122.

12. Ayhan, A., 1983. Aladağ Yöresi Karbonatl $\mathrm{Pb}-\mathrm{Zn}$ Yataklarının Kökeni, TJK Kur. Bül. 26,2,103-116
13. Anıl, M., 1992., Engizek Baritli-Kurşun-Çinko Yataklarının Jeolojik, Metalojenik ve Ekonomik İncelemesi, Tübitak Raporu YBAG005 .

14. Bernard, A.J. 1971. Recyclage Metallogenie Tome I, II, III Ecole de Geologie de NancyFrance.

15. INAP,

2009. www.inap.com.au/GARDGuide.htm

16. Lapakko, K. A., 2002. "Metal Mine Rock and Waste Characterization Tools: An Overview", International Institute for Environment and Development, No:67.

17. Sullivan P.J., Reddy K.J. and Yelton, J.L.,1988 "Iron Sulfide Oxidation and Chemistry of Acid Generation",Environmental Geological Water Science Volume 11,No.3,pp.289-295.

18. Lefebvre, R., Hockley, D., Smolensky, J., and Gelinas, P., 2001. "Multiphase Transfer Processes in Waste Rock Piles Producing Acid Mine Drainage 1: Conceptual Model and system Characterization", Journal of Contaminant Hydrology, 52:pp.137-164.

19. Jaynes, D. B., Roğowski, A. S., Pionke, H.B. and Jockoby Jr. E. L., 1983. "Atmosphere and Temperature Changes with in a Reclaimed Coal Strip Mine", Soil Science, V.136, No:3, pp. 164-177.

20. Colmer, A. R., Hinkle, M.E., 1947. "The Role of Microorganisms in Acid Mine Drainage-A Preliminary Report", Science, v. 106, no. 2747, p. 253-256.

21. Colmer A R, Temple K L, Hinkle M E., 1950. "An Iron - Oxidizing Bacterium from the Drainage of some Bituminous Coal Mines", Journal of Bacteriology, v.59, pp 317-328.

22. Paktunç, A.D., 1998. "Characterization of Mine Wastes for Prediction of Asid Mine Drainage", Environmenta Impacts of Mining Activities, Azcue,J.M.,(Ed). Pp.19-40.

23. Lapakko, K. A.,Wessels, J. N.,1995. "Release of Asid from Hydrotherma.

24. Yadav, S.K., and Chakrapani, G.J., 2006. Dissolution Kinetics of Rock-Water Interactions and Its Iimplications", Current Science, Vol.90, No.7, pp. 932-937.

25. Morin, K.A. and Hutt, N.M., 1997. Environmental Geochmistry of Mines 
Parajenezlerinde Sülfürlü Mineraller İçeren Maden Yataklarında Oluşabilecek Asit Kaya (Maden) Drenajlarının Çevresel Etkileri

Drainage Pratical Theory Case Studies, MDAG Publ. Vancauver Canada.

26. Yörükoğlu, A. ve Karadeniz, M., 2003. “Asit Maden Drenajı Kestirim Yöntemlerinin Karşılaştırılması", Türkiye 18. Uluslararası Madencilik Kongresi ve Sergisi, Ed. Özbayoğlu, G., Doğuşum Matbaacılık, Antalya, s.125-131.

27. Hammarstrom, J. M., Smith, K. S., 2002. Chapter B: Geochemical and Mineralogic Characterization of Solids and their Effects on Waters in Metal-Mining Environments", http://www.pubs.usgs.gov/of/2002/of02-195/. 